\title{
Time for a Paradigm Shift in Animal Nutrition Metabolic Path- way: Dietary Inclusion of Organic Acids on the Production Pa- rameters, Nutrient Digestibility and Meat Quality Traits of Swine and Broilers
}

\author{
Dhanushka Rathnayake ${ }^{1,+}$, Hong Seok Mun ${ }^{1,2,+}$, Muhammad Ammar Dilawar ${ }^{1,2}$, Kwang Soo Baek ${ }^{2}$, Chul Ju Yang \\ 1,2 , * \\ ${ }^{1}$ Animal Nutrition and Feed Science Laboratory, Department of Animal Science and Technology, \\ Sunchon National University, Suncheon 57922, Korea \\ ${ }_{2}^{2}$ Interdisciplinary Program in IT-Bio Convergence System (BK21 plus), Sunchon National University, Suncheon \\ 57922, Korea \\ *Correspondence: yangcj@scnu.kr; Tel.: +82-61-750-3235 \\ + This author contributed equally to this work as co-first author
}

\begin{abstract}
Because the application of antibiotic growth promoters (AGP) causes accelerated adverse effects on the animal diet, the scientific community has taken progressive steps to enhance sustainable animal productivity without using AGP in animal nutrition. Organic acids (OAs) are non-antibiotic feed additives and a promising feeding strategy in the swine and broiler industry. Mechanistically, OAs improve productivity through multiple and diverse pathways: (a) reduction of pathogenic bacteria in the gastrointestinal tract (GIT) by reducing the gut $\mathrm{pH}$; (b) boosting the digestibility of nutrients by facilitating digestive enzyme secretion and increasing feed retention time in the gut system; (c) having a positive impact and preventing meat quality deterioration without leaving any chemical residues. Recent studies have reported the effectiveness of using encapsulated OAs and synergistic mechanisms of OAs combinations in swine and broiler productivity. On the other hand, the synergistic mechanisms of OAs and the optimal combination of OAs in the animal diet are not completely understood, and further intensive scientific explorations are needed. Moreover, the ultimate production parameters are not similar owing to the type of OAs, concentration level, growth phase, health status of animals, hygienic standards, and environmental factors. Thus, those factors need to be considered before implementing OAs in feeding practices. In conclusion, the current review evaluated the basics of OAs, mode of action, novel strategies to enhance utilization, influence on growth performances, nutrient digestibility, quality traits, and meat preservation of swine and broilers and their potential concerns regarding utilization.
\end{abstract}

Keywords: organic acids; swine; broilers; digestibility; meat quality; meat preservation

\section{Introduction}

The ultimate goal in the global livestock sector is to achieve enhanced quantitative and qualitative productive parameters. A few decades ago, enhanced production was gained by incorporating various antibiotic growth promoters (AGP), which resulted in improved feed efficacy, growth rate, and lower mortality and disease. On the other hand, the emergence of antimicrobial resistance bacteria has led to a discussion regarding the global health problem. Consequently, the utilization of AGP was banned by the European Union. Thus, scientists and researchers have focused on sustainable potential antibioticfree production systems in the poultry sector [1] and swine industry [2].

Researches have highlighted the effective utilization of organic acids (OAs), phytobiotics, probiotics, prebiotics, bacteriophages, and other numerous alternatives instead of antibiotics to establish appropriate health and production parameters of animals. OAs 
produced effective responses owing to their antimicrobial properties, which can enhance the $\mathrm{pH}$ reduction rate in the GI tract [3]. Consequently, the intestinal digestibility and mineral utilization were improved [4,5]. Acidifiers were incorporated into animal diets a few years earlier owing to the presence of preservatives and nutritional characteristics $[6,7]$. Despite controlling the desirable growth rate of molds, fungi, bacteria in animal feed, several studies have reported the potential ability of improving nutrition digestion and retention, intestinal health, ultimate growth development of non-ruminant animals, including feed sanitizing characteristics $[8,9,10]$. Enhanced meat quality characteristics and growth performances were observed in broilers fed a diet supplemented with OAs, including 30\% lactic, $25.5 \%$ benzoic, $7 \%$ formic, $8 \%$ citric, and $6.5 \%$ acetic acid [11]. Partanen and Morz [6] reported that incorporating OAs into the pig diet modulates the beneficial gut microbiota and improves the growth performance. A reduced gastric $\mathrm{pH}$ and retarded enterotoxigenic E.coli proliferation in the gut system occurred due to the inclusion of lactic acid into the pig diet. Thus, developed gut health led to optimal feed intake and weight gain of the animal [12]. Furthermore, supplementation of OAs with feedstuff will increase the stimulation rate of the nutrient digestion process [13]. Effective production parameters and health-promoting evidence have been discovered for numerous OAs, such as citric, fumaric, and formic acids and their salts [14]. The application of OAs in the livestock sector has produced numerous benefits in both economic and quality product perspectives in the livestock sector (Figure 1).

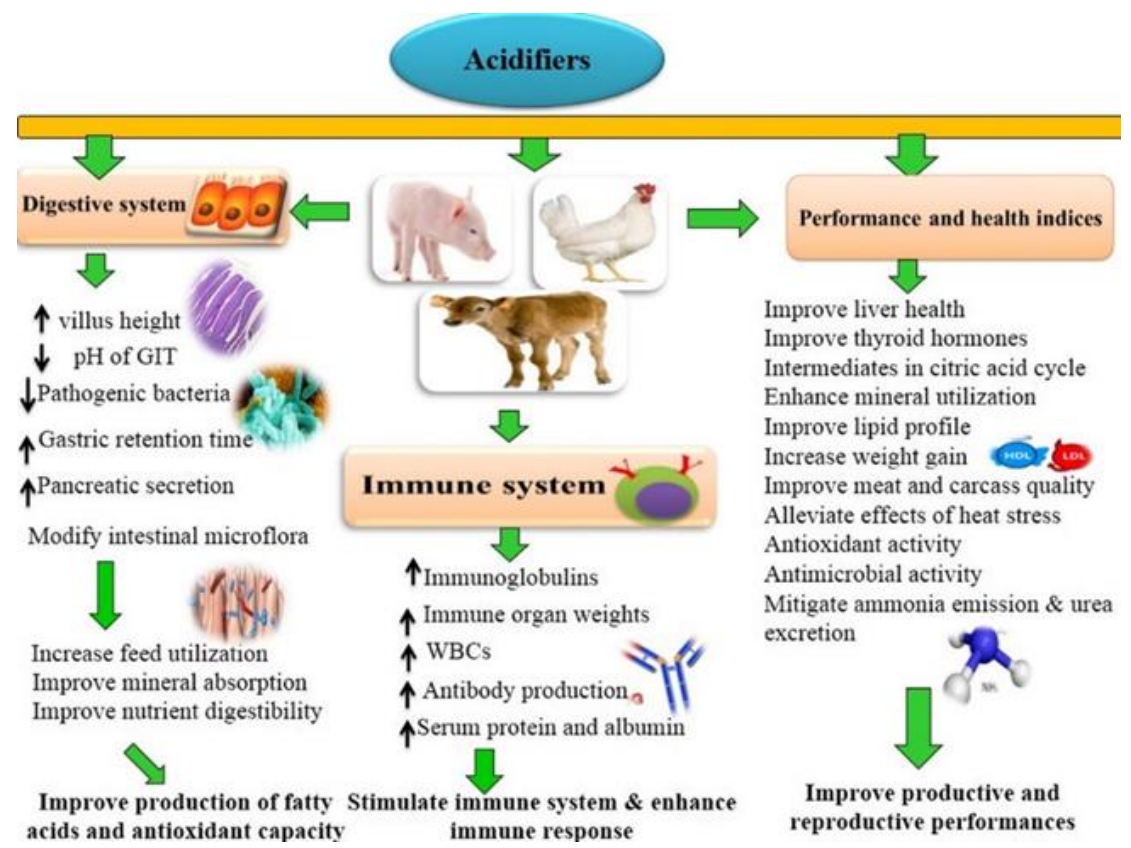

Figure 1. Various application and benefits of OAs in the livestock sector [15].

Chemically, organic acid consists of an organic carboxylic acid group (R-COOH) with fatty acids and amino acids. Moreover, short-chain acids (C1-C7) are involved in antimicrobial activities. Most of them are either simple carboxylic acids, such as acetic, formic, butyric, and propionic acids with a hydroxyl group, such as tartaric, malic, citric, and lactic acids or short-chain carboxylic acids with double bonds, such as sorbic and fumaric acids [16]. On the other hand, Ravindran and Kornegay [17] reported that each organic acid has a distinguished range of $\mathrm{pH}$, antimicrobial potential, $\mathrm{pKa}$ values, and membrane structure. A combination of OAs has various $\mathrm{pKa}$ values, directly influencing the intestine $\mathrm{pH}$ due to the developed synergistic effect. The most common OAs involved in animal nutrition are listed below (Table 1) 
Table 1. Common OAs and their properties involved in animal nutrition $[15,18]$

\begin{tabular}{|c|c|c|c|c|c|}
\hline Acid & Chemical Name & $\begin{array}{l}\text { Regis- } \\
\text { tration } \\
\text { Num- } \\
\text { ber }\end{array}$ & $\begin{array}{l}\text { Molecular } \\
\text { weight/GE } \\
(\mathrm{MJ} / \mathrm{Kg})\end{array}$ & Odor & pKa \\
\hline Butyric & Butanoic Acid & - & $88.12 / 24.8$ & rancid & 4.82 \\
\hline \multirow[t]{3}{*}{ Citric } & 2-Hydroxy-1,2,3- & E 330 & 192.1/10.2 & odorless & 3.13 \\
\hline & Propanetricarboxylic & & & & \\
\hline & Acid & & & & \\
\hline Propionic & 2-Propanoic Acid & $1 \mathrm{a} 297$ & $74.08 / 20.6$ & pungent & 4.88 \\
\hline \multirow[t]{2}{*}{ Sorbic } & 2,4-Hexandienoic Acid & E 200 & $112.1 / 27.85$ & mildly & 4.76 \\
\hline & & & & acrid & \\
\hline Formic & Formic Acid & Е 236 & $46.03 / 5.7$ & pungent & 3.75 \\
\hline Acetic & Acetic Acid & Е 260 & $60.05 / 14.6$ & pungent & 4.76 \\
\hline \multirow[t]{2}{*}{ Lactic } & 2-Hydroxypropanoic & E 260 & $90.08 / 15.1$ & sour milk & 3.83 \\
\hline & Acid & & & & \\
\hline \multirow[t]{2}{*}{ Malic } & Hydroxybutanedioic & Е 296 & $134.1 / 10.0$ & apple & 3.40 \\
\hline & Acid & & & & \\
\hline Fumaric & 2-Butenedioic Acid & $2 b 08025$ & $116.1 / 11.5$ & odorless & 3.02 \\
\hline Benzoic & Benzenecarboxylic acid & - & - & - & 4.20 \\
\hline
\end{tabular}

This review evaluates the response of swine and broilers to OAs supplementation of previous studies in terms of the growth production parameters, including feed intake, weight gain, feed conversion ratio (FCR), nutrient digestibility, and meat quality traits. The possible modes of action, causes of various responses due to OAs, and potential concerns regarding OAs are also assessed.

\section{Potential modes of action of OAs}

OAs have numerous benefits on the health and development of the gut system. Nevertheless, the mode of action is not completely understood. Their modes of action may be attributed partially to different factors, such as (A) mineral chelation and stimulation on intermediary metabolism; (B) inhibition of the development of pathogenic microbes; (C) facilitate proper digestion due to lower gastric $\mathrm{pH}$ and enhanced pepsin secretion; (D) reduction of gastric emptying rate and maintenance of endogenous enzymes secretion $[19,3]$.

2.1 Effect of $O A$ s on mineral utilization and nutrient digestibility 
Mineral utilization is increased by adding OAs to the diet through the reduction of gut $\mathrm{pH}$. Bolling et al. [20] reported that citric acid facilitates the removal of attached minerals to phytate molecules, such as $\mathrm{Ca}, \mathrm{P}$, and $\mathrm{Zn}$. In contrast, $\mathrm{OA}$ anions form complexes with $\mathrm{Mg}, \mathrm{P}, \mathrm{Ca}$, and $\mathrm{Zn}$, improving digestion and minimizing the excretion of beneficial minerals from the body. Phytate phosphorous utilization occurs through OAs administration by providing favorable $\mathrm{pH}$ conditions to convert phytase into hydrolyze phytate. In particular, lower gastrointestinal $\mathrm{pH}$ has the potential to enhance P solubility [21]. It has found that fumaric acid can enhance the apparent absorption and retention of $\mathrm{Ca}, \mathrm{P}$, and $\mathrm{Zn}$ in the GIT [22].

The lower metabolizable energy (ME) in soya bean meal occurs due to retarded digestibility in the carbohydrate portion. Galacto-oligosaccharides in soya bean meal cannot be digested properly without the presence of endogenous $\alpha-(1,6)$-galactosidase in the intestines. Ao [23] reported that the inclusion of $2 \%$ citric acid decreased the crop $\mathrm{pH}$ by enhancing the activity of the $\alpha$-galactosidase enzyme, which increased the digestion process. Moreover, by reducing the chime $\mathrm{pH}$, OAs supplementation improved protein digestion owing to microbial phytase activity and induced pepsin secretion [24]. A further protein digestion process improves through the secretion of a greater level of chymotrypsinogen $A$, chymotrypsinogen $B$, procarboxy peptidase $A$, procarboxy peptidase $B$, and trypsinogen enzymes [25]. OAs inclusion also increased the proper absorption rate of nutrients in the GI tract by increasing the digesta retention time [26]. The increased ME and crude protein $(\mathrm{CP})$ was observed due to the reduced microbial competition with the host, ammonia emission, and endogenous nitrogen elimination [27].

\subsection{Effect of $O A$ s on antimicrobial activity and pathogenic bacteria}

Both animals and plants have symbiotic relationships with various microbes to survive in the environment through an active defense system against pathogens and to regulate the metabolism associated with hormones. On the other hand, an excessive microflora content produces unnecessary competition between the host and nutrition. Hence, maintenance of the optimal microbe composition in the GI tract should be investigated. OAs can be divided into two groups based on the microbial ameliorate capacity in the GI tract (figure 2).
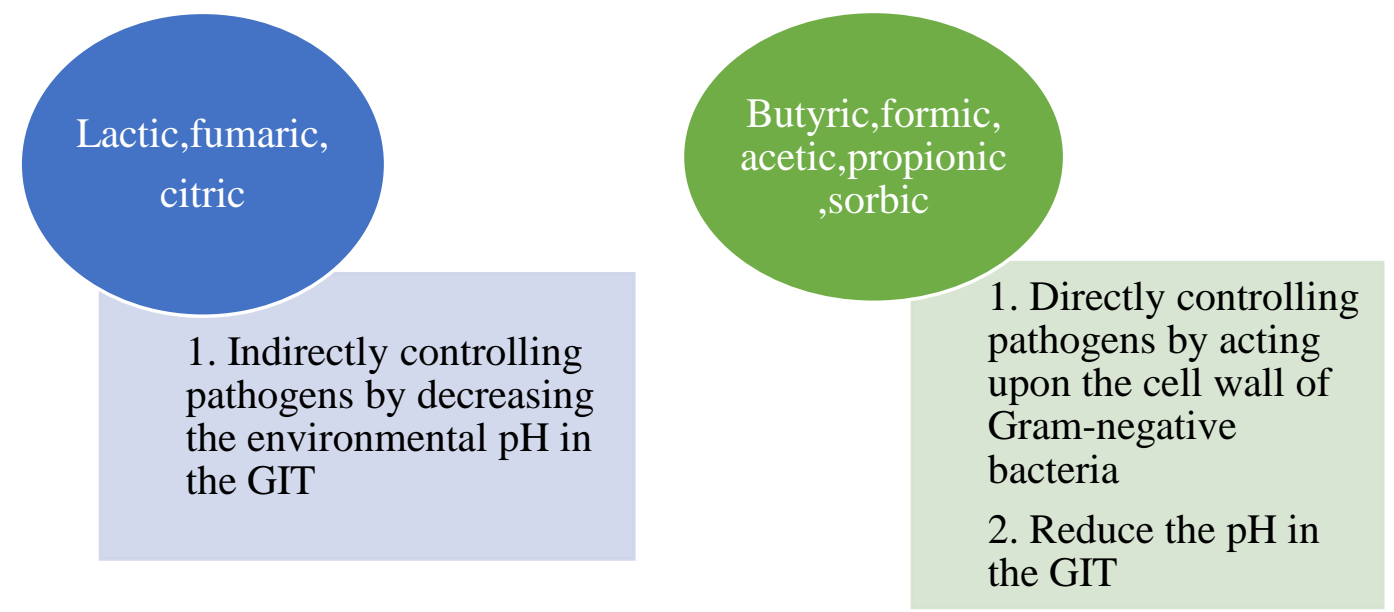

Figure 2. Two different mechanisms of OAs on altering the $\mathrm{pH}$ of the GI tract and their impact on pathogens [28].

Non-disassociated OAs enter the cytoplasm through the semipermeable membrane of the microorganism. Thereafter, OAs release their protons $\left(\mathrm{H}^{+}\right)$, and the cytoplasm $\mathrm{pH}$ 
decreases gradually. The enzymes involving reactions, such as nutrient transportation and glycolysis signal transductions of the microbes, are curtailed. Consequently, an energy deficiency occurs to maintain the normal $\mathrm{pH}$ [29]. Owing to the acidic conditions in the stomach, the efficacy of OAs is greater than under neutral $\mathrm{pH}$ conditions, as in the intestines. On the other hand, most bacteria species require optimal environmental $\mathrm{pH}$ conditions and $\mathrm{pH}<4.5$ (extreme lower) conditions which adversely affect their survival. By releasing $\mathrm{H}^{+}$ions, OAs aid in the dysfunctions, retardation, or inhibition of the multiplication of $\mathrm{pH}$-sensitive bacteria [30].

Moreover, some bacteria in the GI tract secrete various harmful compounds that reduce fat digestibility, rapid turnover of absorptive epithelial cells, stimulate mucus secretion, and induce an immune response due to the developed immune system. These factors help retard the growth performance, and approximately $6 \%$ net energy losses in pigs can be attributed to microflora [31]. OAs have the potential to eliminate specific species, such as coliforms, while generating eubiosis. Thus, they can provide the optimal microbial atmosphere in the GI tract that can benefit the host by accumulating lower toxic compounds, amines, and ammonia. On the other hand, gram-negative (G-) bacteria resist OAs that consist of more than eight carbon bonds to some extent, gram-positive $\left(\mathrm{G}^{+}\right)$bacteria are susceptible to long-chained OAs [32,33]. Stronger effects of OAs affect $\mathrm{G}^{+}$bacteria due to cell structural differences. In contrast, the cytoplasmic membrane of bacteria is surrounded by a thick peptidoglycan layer. Generally, this peptidoglycan layer is thicker in $\mathrm{G}^{+}$bacteria than $\mathrm{G}^{-}$bacteria. Nevertheless, $\mathrm{G}$ - bacteria have an extra lipopolysaccharide layer that is more resistant to hydrophobic antibiotics and chemical compounds.

Because OAs have both bactericidal and bacteriostatic properties, Luckstadt and Mellor [34] sketched out the mode of action of OAs on $\mathrm{G}^{-}$bacteria as follows. (1) Lipophilic undissociated OAs penetrate the $\mathrm{G}^{-}$bacteria cytoplasm (Salmonella). (2) OAs release $\mathrm{H}^{+}$ions, which reduces the cellular $\mathrm{pH}$, and the enzyme-based microbial metabolism tends to decrease (3). To restore the normal cytoplasmic $\mathrm{pH}$, the cell is forced to discard $\mathrm{H}^{+}$ions through the cell membrane via the $\mathrm{H}^{+}$- ATPase pump. (4) Ultimately, $\mathrm{G}^{-}$bacteria proliferation is gradually impeded when exposed to OAs for some time (Figure 3).

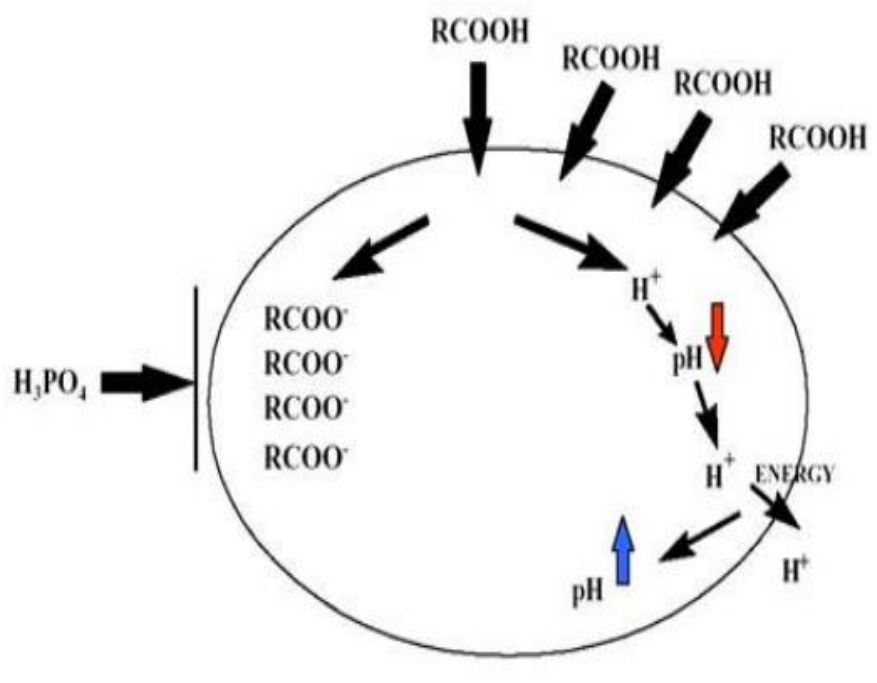

Figure 3. Mode of action of OAs on $\mathrm{pH}$-sensitive bacteria (Clostridia, Salmonella, Coliforms, listeria spp.) [35]. 
This anion model of OAs can vary upon two factors: (1) The lipophilic nature of the OAs, which can transmit through the microbes cell wall; (2) various anion complexes involves with different inhibitory actions within the cell $[36,37]$. Some OAs can alter the GI tract by eradicating foodborne pathogens, such as salmonella and E.coli species [38]. Owing to $\mathrm{pH}$ reduction and their influence on the buffering capacity of the diet, OAs can improve gut health by providing the optimal environment to beneficial microbes while preventing the proliferation of pathogens $[6,39,40]$.

\section{Novel strategies for enhancing efficacy OAs availability in the gastrointestinal tract (GIT)}

The supplementation of feed and water with OAs did not show better efficacy in the latter part of the GI tract. It occurs due to the high proportion of short-chain fatty acids (SCFA) that are metabolized and absorbed rapidly in the upper segments of the GI tract [41]. Thus, the OAs concentration tends to decrease and exert negative feedback on modifying the host microflora content in the GI tract. New studies have shown that microencapsulated lipid shells facilitate the transportation of SCFA further down the GI tract while increasing the retention time [41,42]. Furthermore, microencapsulated feed improves palatability, removes unpleasant odors/ flavors, and delivers the necessary compounds to the specific target place inside the animal body while acting as a "biological agent" (2). Further studies have demonstrated that the efficiency of OAs can be improved by incorporating phytogenic feed additives. Owing to the synergistic effects of both OAs and botanicals, food-safety bacteria, such as C. jejuni and S. typhimurium counts, tend to decrease. In particular, pore-forming agents derived from numerous aromatic compounds caused changes in the bacterial cell membrane by providing a pathway for OAs entrance [43,44]. Grilli et al. [45] indicated that a combination of microencapsulated OAs (citric and sorbic acid) and pure botanicals in weaning pigs' diet improved the maturation of the intestinal mucosa by exerting a positive impact on the barrier integrity in the jejunum and ileum while performing better growth performance. Gheisar et al. [46] observed a higher lactobacillus content in the feces of broilers fed a diet supplemented with $0.075 \%$ microencapsulated OAs. Gheisari et al. [47] also reported that $0.2 \%$ OAs inclusion enhanced the lactobacillus content while reducing the Clostridium perfringens, E. coli, and Salmonella spp content. Moreover, a 0.5\% microencapsulated blend of OAs reduced the oxidative status, microbial loads, and improved the shelf life of broiler meat [48]. The protected OAs could be delivered to specific sites in the body and had a positive effect by eliminating the coliforms counts in both the distal jejunum and cecum. In contrast, freely available OAs had little influence [49].

Since the form of OAs (SCFA) is naturally produced by the GI tract, some studies reported that introducing both prebiotics and probiotics could stimulate the synthesis of SCFAs in the GI tract [50,51]. This could be implemented in two ways: (1) direct administration of lactic acid-producing bacteria in the diet; (2) the addition of prebiotic substances that enhance the proliferation of lactic acid bacteria and increase SCFA production $[52,53]$.

Streptococcus, Saccharomyces, Enterococcus, Lactobacillus, Bacillus, Bifidobacterium, and Pediococcus are the probiotic strains mainly used in nutritional studies. These microbes protect the GI tract through barrier effects, competitive exclusion, bacterial interference process, prevention of colonization, and bacterial antagonism [54,55]. These probiotic supplementations develop the cell structure, have immunological effects, and are resistant to pathogens. Ultimately, they enhance the production rate of SCFAs, intermediary products, and $\mathrm{H}_{2} \mathrm{O}_{2}$. Lactobacillus spp. can generate lactic acid, which can facilitate the synthesis of butyric acids with the collaboration of Clostridial clusters that reinforce the animal crossfeeding process [56]. Oligosaccharides and polysaccharides (Non- digestible carbohydrates (NDC)), proteins, and particular lipids are used as prebiotics to provide a proper 
substrate for beneficial host microbes. Previous studies have stated that the administration of prebiotics has a positive effect on the natural production of OAs in the GI tract. The supplementation of the diet with NDC enhances the lactobacillus and bifidobacterium population. In contrast, these microbes promote the synthesis of SCFA, such as propionate, acetate, and butyrate acids [57]. Rehman et al. [58] reported that $1 \%$ inulin inclusion increased the jejunum acetate concentration and n-valerate in the cecal digesta in broilers compared to the control diet. Overall, the dietary supplementation of prebiotics and probiotics will lead to optimal OAs production in the animal body.

\section{Effect of OAs in swine and broiler}

\subsection{Supplementation of OAs on the growth performance of swine and broilers}

Studies have found that the optimal dosage of OAs can enhance the productivity of pigs compared to AGPs. Increased growth performance, gain to feed (G: F), and feed intake (FI) was observed in piglets supplemented with an OAs mixture (benzoic, fumaric, lactic, propionic, and citric) [59]. Because benzoic acid in the diet can increase the butyric acid concentration in the GI tract, the gut microflora ameliorating process occurs by acting as an energy source agent in gut epithelial cells [60]. The feed conversion ratio (FCR) was increased by $10 \%$, and the average daily gain (ADG) was increased by $3 \%$ when pigs were administered fumaric and citric acids at four weeks of age [61]. Kuang et al. [62] reported that the inclusion of an OAs blend (calcium formate, calcium lactate, and citric acid) and medium-chain fatty acids (MCFAs - lauric, capric, and myristic) enhanced the FI, ADG, and FCR in weaning pigs compared to pigs fed with dietary zinc oxide inclusion. Feeding weaning pigs with $0.8 \%$ fumaric acids reduced the E.coli and coliforms population in the cecum [63]. On the other hand, Risley et al. [64] reported that $1.5 \%$ fumaric acid addition did not affect the microflora composition in the GI tract. According to the study conducted by Htto et al. [65], the ADG, FCR, and BW during 0-14 days (piglets) were not significantly different from those fed OAs. In the same study, however, the ADG and FCR were enhanced during 15-35 days and overall 35 days of periods due to potassium diformate and potassium formate supplementation. Furthermore, a trend of developed growth performance in response to the inclusion of OAs combined with salts combination was more reliable in growing-finishing pigs than in weaning pigs [6]. Canibe et al. [66] and Partanen et al. [67] reported increased ADG and G: F ratios in pigs fed a diet containing formic acidammonium formate and formic acids. A combination of phytogenic feed additives with organic acids (10\% citric, $10 \%$ sorbic, $6.5 \%$ malic, and $13.5 \%$ fumaric acid) also improved the BW and ADG of weaning pigs. Moreover, Yang et al. [68] reported that the high abundance of Lactobaillus mucosae also occurred compared to the control treatment. Nevertheless, $1.8 \%$ formic acid inclusion did not have a positive response on the ADG and ADFI of weaning pigs, but it enhanced the G: F [66]. The above dissimilarities among the different studies might be related to the inclusion dosage of OAs, diet complexity, growth phase, and animals' health conditions. Therefore, further studies will be needed to identify the best OAs concentration for different growth stages.

In the broiler growth performance, the utilization of OAs has not gained as much attention as in the swine industry. The rapid metabolization process in crops to the gizzard (foregut) causes a deficiency of OAs availability and retards the growth performance [34]. On the other hand, Fascina et al. [11] reported that the administration of OAs combination (30\% lactic, $25.5 \%$ benzoic, $7 \%$ formic, $8 \%$ citric, and $6.5 \%$ acetic acid) improved the BW, WG, and FCR compared to the control group at 42-day-old broilers. The supplementation of $3 \%$ fumaric acid could increase the WG and FCR in broilers compared to the diet comprised of $3 \%$ lactic acid. OAs-included diets resulted in a lower voluntary feed intake (VFI) because of the presence of strong flavor compounds. The improved FCR might have occurred due to lower VFI, which resulted in enhanced BWG because of the efficient nutrients utilization in the body [69]. Hassan et al. [70] reported that microencapsulated galliacid OAs mixture (fumaric acid, calcium formate, calcium propionate, potassium sorbate, 
and hydrogenated vegetable oil) enhanced the WG by $16 \%$ compared to the control groups. Kamal and Ragaa [71] also indicated that in 42 days old broilers, the BWG and FCR were enhanced in those fed $3 \%$ organic acids (butyric, fumaric, and lactic acid). Hence, the higher BWG was achieved through direct antimicrobial effect, reducing the digesta $\mathrm{pH}$ level in the GI tract while acting as a barrier to pathogens, and buffering reactivity in conjunction with the enhanced nutrient digestibility [72]. Interestingly, the synergistic effects of combined $0.3 \mathrm{~g} / \mathrm{kg}$ essential oils with OAs $(200 \mathrm{~g} / \mathrm{kg}$ sorbic, $200 \mathrm{~g} / \mathrm{kg}$ fumaric, and $100 \mathrm{~g} / \mathrm{kg}$ thymol) increased the FCR significantly while minimizing the E.coli population through a lower gut $\mathrm{pH}$ value [73]. 


\begin{tabular}{lllll}
\hline Dosage and Organic acid/acids & & \multicolumn{3}{c}{ Growth performances } \\
\cline { 3 - 4 } & Growth & BWG/FBW ADFI G:F & Intestinal/fecal mi- Other parameters \\
\cline { 3 - 5 } & & & crobial counts & \\
& & (CFU)
\end{tabular}

\section{Swine}

$0.1 \%$ \& $0.2 \%$ fumaric, citric, malic, Weaning S NS S

E.coli; S

MCFA (capric and caprylic)

$0.1 \%$ \& $0.2 \%$ fumaric, citric, malic, Growing MCFA (capric \& acrylic)

$0.15 \%$ benzoic, fumaric, calcium for- Weaning mate

1.1\% acetic, propionic, phosphoric, Weaning NS citric acid

S

Lactobacillus; S

a. Reduced diarrhea score, feca

Yang et al.,

Clostridium; S

Salmonella; S

E.coli; NS

ammonia, and acetic acid emission

2018 [74]

a. Increased villus height in duodenum and jejunum

Upadhya et

al., $\quad 2016$

[75]

$\mathrm{Xu}$ et al.,

b. Increased butyric acid level in the cecum and valeric acid level in the colon

$\begin{array}{ccc}\text { NS NS Lactobacilli; NS } & \text { a. Reduced pH level in colon } & \text { Namkung } \\ \text { E.coli; NS } & \text { et al., } 2004\end{array}$




\begin{tabular}{|c|c|c|c|c|c|c|c|}
\hline & & & & & Coliforms; NS & $\begin{array}{l}\text { b. Retardation of coliform prolifer- } \\
\text { ation }\end{array}$ & [77] \\
\hline $\begin{array}{l}0.4 \% \& 0.2 \% \text { fumaric, lactate, citric, } \\
\text { propionic, benzoic acid }\end{array}$ & Weaning & NS & NS & NS & E. coli; NS & - & $\begin{array}{l}\text { Walsh et al., } \\
2007 \text { [59] }\end{array}$ \\
\hline $0.5 \%$ benzoic acid & Weaning & S & $\mathrm{S}$ & S & Lactobacilli; S & - & $\begin{array}{l}\text { Wei et al., } \\
2021[78]\end{array}$ \\
\hline $0.5,1 \%$ benzoic acid & Weaning & S & NS & NS & $\mathrm{NE}$ & $\begin{array}{l}\text { a. Reduced the number of aerobic, } \\
\text { total anaerobic, lactic acid-forming, } \\
\text { and gram-negative bacteria in the } \\
\text { stomach } \\
\text { b. Reduced gram-negative bacteria } \\
\text { and acetic acid in the duodenum } \\
\text { c. Reduced gram-negative bacteria } \\
\text { in ileum }\end{array}$ & $\begin{array}{l}\text { Kluge et al., } \\
2005 \text { [79] }\end{array}$ \\
\hline $0.5 \%$ butanoic, fumaric , benzoic acid & piglets & S & NS & S & $\begin{array}{l}\text { Lactobacilli; NS } \\
\text { E.coli; NS }\end{array}$ & $\begin{array}{l}\text { a. Decreased ileal E.coli bacteria } \\
\text { level } \\
\text { b. Did not exert negative impacts } \\
\text { on GI tract pH level and immunity }\end{array}$ & $\begin{array}{l}\mathrm{Li} \text { et al., } \\
2008[80]\end{array}$ \\
\hline
\end{tabular}

.

(

.


$0.1 \%$ fumaric, citric, malic, MCFA Finishing $\mathrm{S}$ (capric \& caprylic)

0.85\% formic, benzoic, sorbic, Ca- bu- Growing NS

tyrate

male pigs

$0.5 \%$ benzoic acid

Weaning

S

Weaning S

$0.14 \% \& 0.64 \%$ formic acid
NS

S

NS
NS E. coli; S
Lactobacilli; S

S

S E.coli; NS

Lactobacilli; NS

S

NS Lactobacilli; $\mathrm{S}$ a. Reduced feces $\mathrm{H}_{2} \mathrm{~S}$ gas emission

padhya et

al., $\quad 2014$

[81]

a. Lower level of coliforms, entero-

Øverland et cocci and lactic acid bacteria in jeju-

al., $\quad 2007$

num and colon descendens

[82]

a. Reduced diarrhea in weaning Papatsiros

pigs

et al., 2011

[83]

a. Higher microbiota diversity in Luise et al.,

$0.64 \%$ dosage

2017 [84]

\section{Broilers}

$0.3 \% \& 0.4 \%$ calcium formate, calcium Finishing S

propionate

0.3, $0.4 \%$ ammonium formate, ammo-

nium propionate

$1 \%$ formic, lactic, propionic, citric acid Finishing S count

b. Improved villi length al., $\quad 2020$

[85]

NS NS NE
a. Enhanced V:C in GI tract
Ali et al.,
b. Increased water consumption
$2020[86]$ 


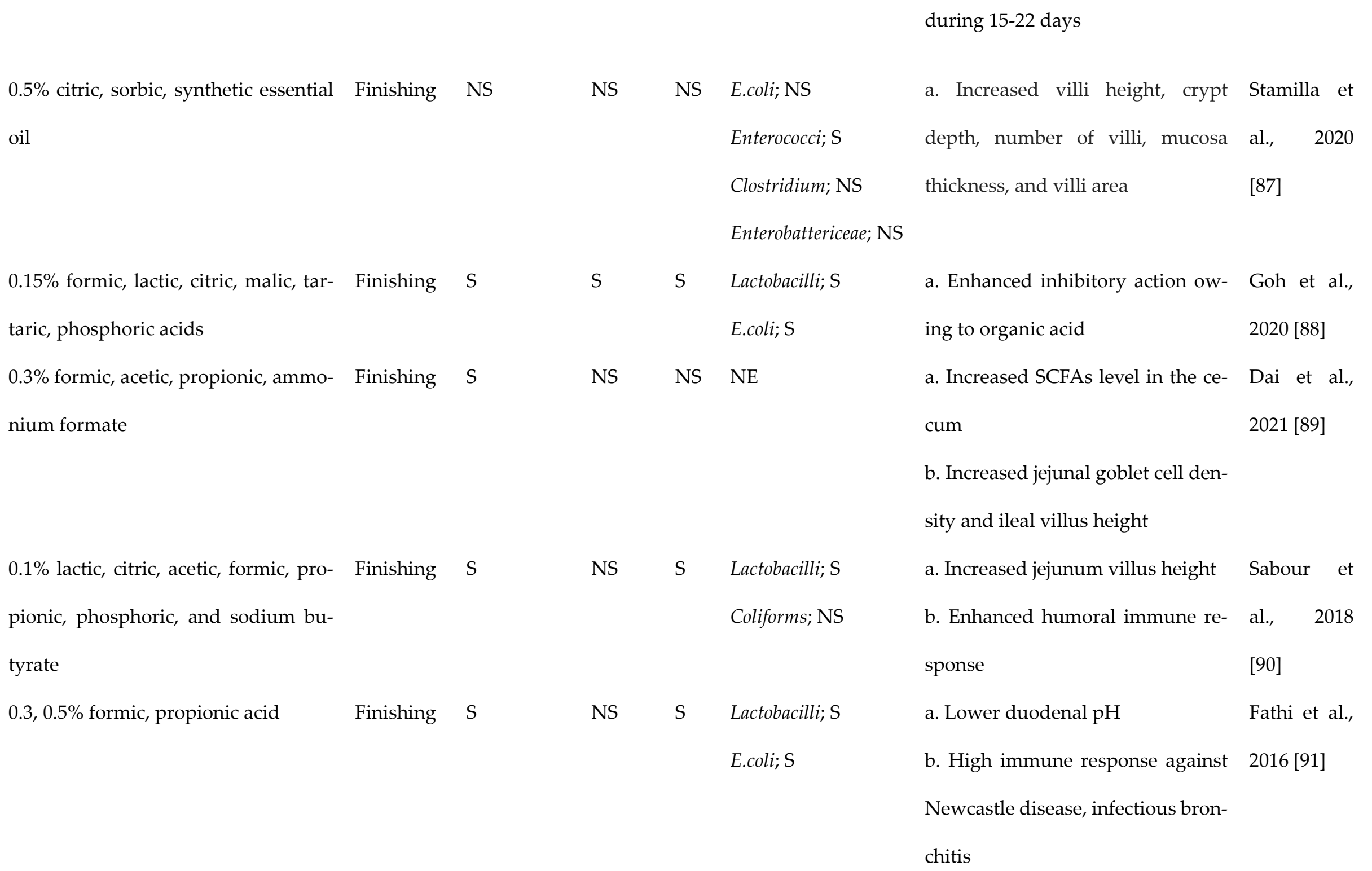

$0.5 \%$ citric, sorbic, synthetic essential Finishing N

oil

taric, phosphoric acids

taic, phosphoric acids nium formate

$0.1 \%$ lactic, citric, acetic, formic, propionic, phosphoric, and sodium bu-

tyrate
$0.3,0.5 \%$ formic, propionic acid

西

doi:10.20944lpreprints202104.0085.v1

during 15-22 days

a. Enhanced inhibitory action ow- Goh et al.,

a. Increased SCFAs level in the ce- Dai et al.,

b. Increased jejunal goblet cell density and ileal villus height a. Increased jejunum villus height Sabour et chitis 
$0.6 \%$ fumaric, calcium format, cal- Finishing $S$

cium propionate, potassium sorbate,

hydrogenated vegetable oil

$0.1 \%$ citric acid, calcium formate, cal-

cium butyrate, calcium lactate

$0.2,0.4 \& 0.6 \%$ butyric acid

Finishing $S$

$0.5,1,1.5 \& 2 \%$ citric , lactic, phos-

phoric acid

Finishing $S$

$0.6 \%$ formic acid

$2 \%$ butyric, fumaric, lactic \& $3 \%$ bu- Finishing

S

tyric, fumaric, lactic acid
S

S

Lactobacilli; S

Salmonella; S
NS

S

E.coli; S

NS

S E.coli; $\mathrm{S}$

Salmonella; S

NS

S

E.coli; S (in crop) a. Increased dressing percentage

and bursa weight

a. $\mathrm{pH}$ reduction of upper GI tract

b. Increased villus length and crypt depth in the duodenum

a. $2 \%$ OAs blend enhanced the carcass yield

b. $1.5 \%, 2 \%$ OAs blend increased the liver weight

a. Higher digestibility of crude protein, high dressed yield, and lower fat content in carcass [94]

NS S NE


phosphorus concentrations

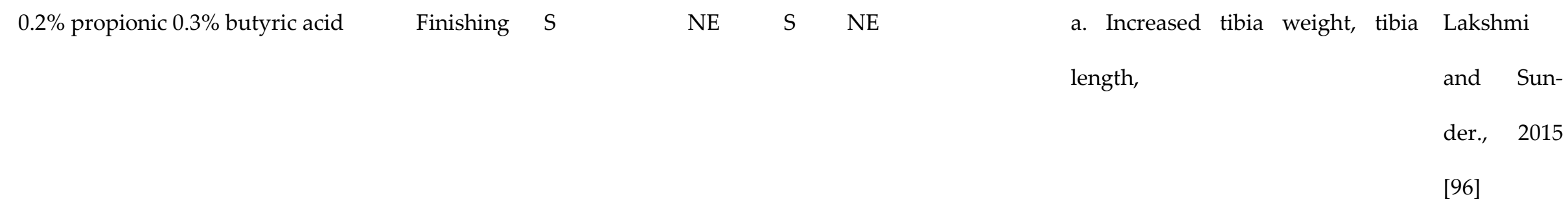

BWG: body weight gain; FBW: final body weight; ADFI; average daily feed intake; G: F; gain to feed ratio; S: Significant; NS: Non-significant; NE: Not-evaluated 
Microencapsulated OAs, including 10\% malic, 13\% citric, and 17\% fumaric acids, enhanced the digestion of $\mathrm{N}, \mathrm{DM}$, and energy in finishing pigs and lactating sows $[81,97,98]$ and significantly increased DM, CP, fat, and energy digestibility in growing pigs [99]. The supplementation of $1.5 \%$ citric acid increased the coefficient of the total tract digestibility (CTTAD) of crude protein $(\mathrm{CP})$, calcium $(\mathrm{Ca})$, and phosphorous $(\mathrm{P})$ of sows during the late gestation and lactation period [100]. Moreover, Yang et al. [101] stated that protected OAs incorporation has positive effects on the apparent total tract digestibility (ATTD) of dry matter (DM) in weaning pigs. The inclusion of benzoic acid resulted in improved apparent digestibility of $\mathrm{Ca}$ and $\mathrm{P}$ in growing pigs $[102,103]$; CP content in weaning pigs [104]; and the DM, CP, ether extract (EE), and crude fiber (CF) of sows [105]. Nevertheless, Upadhya et al. [75] reported inconsistent results in that dietary supplementation of $0.1 \%$, $0.2 \%$, and $0.4 \%$ OAs blends did not influence the digestibility DM, nitrogen $(\mathrm{N})$, and energy favorably in growing pigs.

Since OAs were used as an alternative feed additive, they help improve the growth performance and productivity parameters in broilers. The addition of $0.5 \%$ and $1 \%$ formic acid into the finisher diet was enhanced apparent ileal digestibility (AID) of DM and CP compared to the control treatment $[106,107]$. Ao et al. [108] reported that $2 \%$ citric acid incorporation improved the retention of $\mathrm{DM}, \mathrm{CP}$, and neutral detergent fiber content in the GI tract. Another study revealed that at nine days of age, the gross energy, $\mathrm{CP}$, and $\mathrm{EE}$ digestibility were $78.01,76.07$, and $72.85 \%$, respectively, in diets supplemented with 200 ppm ascorbic acid [109]. The supplementation of $0.2 \%$ OAs with a phytase combination significantly enhanced the $\mathrm{CP}(0.8858)$ and $\mathrm{EE}(0.8561)$ digestibility in chicks than the $\mathrm{CP}$ (0.7751) and EE (0.7949) values in the control treatment [110]. The reason for the higher $\mathrm{N}$ retention might have been the improved epithelial cell proliferation in the GI tract, while non-protected OAs tended to be metabolized rapidly [111].

In contrast, $\mathrm{Hu}$ and Guo [112] explained that the disassociation of fat-coated OAs and their bioactive compounds in the GI tract would help modulate the gut microflora content and mucosal morphology of chickens. Smulikowska et al. [113] reported that fat-coated OAs inclusion improved the N retention, OM, and AMEN values. Owing to the synergistic effect, combined OAs and essential oil (EO) administration into the broiler diet enhanced the AID of DM and energy at 21 days of rearing [114]. Nevertheless, the expected synergism effect was not observed from the combination of citric acid with microbial phytase. The non-significant impact on the AID of CP and amino acids (AA) might be associated with the formation of complexes among citric acids with $\mathrm{Ca}$ and the subsequent decrease in binding ability with phytate allowing easy hydrolyzation by the enzymes [115].

9 10 11 12 13 14 15 16 17 18 19 20 


\begin{tabular}{|c|c|c|c|c|c|c|}
\hline \multirow[t]{2}{*}{ Dosage and Organic acid/acids } & \multirow[t]{2}{*}{ Growth phase } & \multicolumn{4}{|c|}{ Digestibility } & \multirow[t]{2}{*}{ Reference } \\
\hline & & DM & $\mathbf{N}$ & $\mathrm{E}$ & $\mathrm{CP}$ & \\
\hline \multicolumn{7}{|l|}{ Swine } \\
\hline $\begin{array}{l}0.2 \% \text { fumaric, citric, malic, cap- } \\
\text { ric, and caprylic acid }\end{array}$ & Growing & $S$ & $S$ & $S$ & $S$ & Hossain et al., 2011 [99] \\
\hline $0.05 \%$ citric, sorbic acid & Growing & S & NS & S & NC & Cho et al., 2014 [116] \\
\hline $2 \%$ benzoic acid & lactating sows & $\mathrm{S}(\mathrm{OM})$ & $\mathrm{NE}$ & $\mathrm{NE}$ & $S$ & Kluge et al., 2010 [117] \\
\hline $\begin{array}{l}0.1 \% \& \quad 0.2 \% \text { fumaric, citric, } \\
\text { MCFA }\end{array}$ & finishing & $S$ & S & $S$ & NE & Upadhaya et al., 2014 [97] \\
\hline $0.5 \%$ phenyllactic acid & Weaning & $S$ & $S$ & $\mathrm{NE}$ & NE & Wang et al., 2009 [118] \\
\hline $\begin{array}{l}0.3 \% \text { formic, acetic, propionic, } \\
\text { MCFA }\end{array}$ & Weaning & $\begin{array}{l}\mathrm{S}(\mathrm{DM}) \\
\mathrm{NS}(\mathrm{OM})\end{array}$ & NS & NS & NS & Long et al., 2018 [119] \\
\hline $\begin{array}{l}0.5 \% \text { formic, propionic, lactic, cit- } \\
\text { ric, sorbic acid }\end{array}$ & post-weaning & NS & NS & NS & NS & Gerritsen et al., 2010 [120] \\
\hline $\begin{array}{l}300 \mathrm{mEq} \text { acid/kg formic, n-bu- } \\
\text { tyric acid }\end{array}$ & Growing & S & S & S & $\mathrm{S}$ & Mroz et al., 2000 [121] \\
\hline $0.15 \%$ citric acid & Lactating sows & $\mathrm{NE}$ & NE & $\mathrm{NE}$ & $\mathrm{S}$ & Liu et al., 2014a [122] \\
\hline $\begin{array}{l}0.2 \% \text { fumaric , citric, malic , cap- } \\
\text { ric, caprylic acid }\end{array}$ & Lactating sows & S & S & S & $\mathrm{NE}$ & Devi et al., 2016 [123] \\
\hline
\end{tabular}




\begin{tabular}{|c|c|c|c|c|c|c|}
\hline Broilers & & & & & & \\
\hline $0.2 \%$ formic, propionic acid & Finishing & NS & NE & NE & $S$ & Emami et al., 2013 [124] \\
\hline $0.5 \%$ formic acid & Finishing & NS & NE & NE & NS & Hernández et al., 2006 [106] \\
\hline $0.25,0.5 \& 0.75 \%$ formic acid & Finishing & NS & NE & NE & $S$ & Ndelekwute et al., 2015 [125] \\
\hline $\begin{array}{l}\text { 5000ppm and 10,000ppm formic } \\
\text { acid }\end{array}$ & Finishing & $S$ & NE & $\mathrm{NE}$ & $S$ & Garcia et al., 2007 [107] \\
\hline $\begin{array}{l}0.25 \% \text { acetic, butyric, citric, for- } \\
\text { mic acid }\end{array}$ & Finishing & $S$ & $\mathrm{NE}$ & NS & $S$ & Ndelekwute et al., 2019 [145] \\
\hline $1,2 \& 3 \%$ citric acid & Finishing & $\mathrm{NE}$ & $\mathrm{NE}$ & $S$ & $S$ & Ghazalah et al., 2011 [127] \\
\hline $0.5,1 \& 1.5 \%$ fumaric acid & Finishing & $\mathrm{NE}$ & $\mathrm{NE}$ & $S$ & $S$ & Ghazalah et al., 2011 [127] \\
\hline $0.25,0.5 \%$ formic acid & Finishing & NE & NE & NS & $S$ & Ghazalah et al., 2011 [127] \\
\hline $0.25,0.5 \& 0.75 \%$ acetic acid & Finishing & NE & NE & $S$ & NS & Ghazalah et al., 2011 [127] \\
\hline
\end{tabular}

N. nitrogen; E: energy; CP: crude protein; S: significant; NS: non-significant; NE: not-evaluated; OM: organic matter; DM: dry matter 
Few studies have investigated the meat quality parameters based on the incorporation of OAs in animal diets. On the other hand, an examination of the meat quality traits of pork and broilers is important because the consumption of qualitative meat has gained an important place in the food industry. Upadhya et al. [97] reported that supplementation of an OAs blend (consisting of fumaric, citric, malic, and MCFA) did not have adverse effects or improve the meat color. Furthermore, other analyzed parameters, including $\mathrm{pH}$, cooking loss, drip loss, and water holding capacity (WHC), were not influenced by the inclusion of OAs. Similarly, Cho et al. [128] reported that the administration of a microencapsulated OAs combination, including citric and sorbic acids, did not affect the meat color, $\mathrm{pH}$, sensory attributes (color, firmness, marbling), cooking loss, and WHC. In contrast, the inclusion of 0.05 and $0.1 \%$ fumaric, citric, malic, and MCFAs resulted in lower drip loss in pork, except for any differences in meat color, sensory evaluation, cooking loss, $\mathrm{pH}$, and WHC. Further investigations will be needed to determine the possible mode of actions associated with the meat quality characteristics by introducing OAs to the animal diet. Jansons et al. [129] reported a higher protein content in muscle tissues and lower cholesterol content in pork after the addition of formic, acetic, citric, phosphoric acid along with phytogenic feed additives to the diet. This might be attributed to the synergistic effect and the presence of antioxidant compounds in the feed.

Brzóska et al. [130] reported that the supplementation of OAs to a broiler diet resulted in an increased breast muscle content and decreased leg muscle weight. The chemical constitutes of the leg meat, including DM, protein, and fat content, did not vary due to OAs application. Supplementation at the recommended dosage of an acetic, butyric, formic, phosphoric, lactic acid blend did not have significantly favorable results on carcass $\mathrm{pH}$, shear force, WHC, cooking loss, and meat color values, but the TBARS value was enhanced significantly in birds fed with an OAs mixed diet. The suggests that a higher fat content facilitated a higher lipid oxidation process in meat [131]. Lower meat $\mathrm{pH}$ resulted in the metabolism of the glycogen reserves and subsequent $\mathrm{H}+$ emission through the ATP hydrolysis process. Thus, meat $\mathrm{pH}$ has a significant impact on determining the meat quality traits [132]. In contrast, at a lower $\mathrm{pH}$ range $(\mathrm{pH}<5.8)$, broiler meat exhibited a pale, soft, and exudative (PSE) condition, which is considered a degraded meat quality parameter compared to meat exposed to higher $\mathrm{pH}$ levels $(\mathrm{pH}>5.8)$. Sugiharto et al. [133] found that a higher meat $\mathrm{pH}$ in broilers occurred in a diet administered with $0.1 \%$ formic and $0.3 \%$ butyric acid compared to the control group. El-Senousey et al. [134] presented a possible reason for the OAs and higher meat $\mathrm{pH}$ occurrence; the decline in post-mortem muscle glycolysis inhibited the decrease in muscle $\mathrm{pH}$ after slaughter. Furthermore, lower drip loss and a lightness value were reported in the diet combined with both formic and butyric acid but decreased due to the single administration of butyric acid. This might be due to the distinctive characteristics of each OA and their metabolic activities associated with their specific pKa. Menconi et al. [135] and Shin et al. [133] reported less drip loss in broiler meat with feeding blends of lactic, tannic, caprylic, propionic, acetic acids, and butyric acid. Nevertheless, inconsistent results were obtained by Attia et al. [136], who reported a decrease in WHC in broiler meat owing to the supplementation of citric and fumaric acids. These results were attributed to differences in the OAs type, dosage, and experimental environment. Göksoy et al. [137] reported a numerical reduction of meat lightness owing to the combination of lactic, formic, and propionic acids. Similarly, Sughirto et al. [133] and Jha et al. [138] reported lower meat lightness in broiler meat along with OAs administration. The possible cause might be the destruction of the myoglobin content and subsequent reduction of the meat redness.

Moreover, Jha et al. [138] reported that the inclusion of OAs (formic + propionic acid, formic + citric acid, formic + sorbic, and formic+ lactic acid) enhanced the meat thigh weight, back weight, wings weight, and breast weight compared to the control group. On 
the other hand, they did not evaluate any other meat quality parameters regarding OAs inclusion. Lower saturated fatty acid (SFA) and higher polyunsaturated fatty acid (PUFA) contents of meat reduce the risks on human health. Because promising feeding strategies directly influence the meat quality parameters, it is important to discover effective feeding techniques to ensure the safety and quality of the meat. Akbar et al. [139] observed a significantly higher PUFA content and lower SFA proportion than the birds fed a basal diet. Furthermore, a lower cholesterol content was also reported in the diet containing dietary OAs. Heat stress is considered one of the significant issues that have adversely affected the global poultry sector. Previous studies found that acute heating conditions led to a decrease in meat $\mathrm{pH}$, lightness of major muscle tissues, and increased cooking losses [140]. On the other hand, He et al. [141] stated that a diet supplemented with fumaric acid for birds under heat stress helped alleviate the poorer meat quality traits, including excessive $\mathrm{pH}$, drip loss, and cooking loss.

\subsection{Effects of the incorporation of $\mathrm{OAs}$ on meat preservation}

Meat preservation and protecting its organoleptic properties contribute to the consumer's nutritional trends, food safety, and qualitative characteristics of meat. Consumers' demand for natural food consumption has increased gradually, resulting in increased interest in the modern "biopreservation" process in the meat industry. Thus, OAs administration acts as a bio-preservation agent in animal source-based food products [142]. The most widely used OAs in meat product preservation are acetic, lactic, propionic, sorbic, benzoic, citric acids, and sulfites, which can disrupt the proliferation and colonization of pathogenic microbes [143]. Despite ameliorating the microbial activities, OAs influenced the development of sensory attributes, physical properties, such as stabilization, color, and regulation of acidity [144,145]. Nair et al. [146] reported that incorporating sorbic acid in meat products could inhibit mold growth while not affecting the lactic acid bacteria population, thereby ensuring the beneficial preservative characteristics of fermented meat products.

The addition of sodium lactate at 1.5 and 3\% favorably enhanced the sensory attributes and shelf life of fresh ground pork. Furthermore, it enhanced the meat juiciness and flavor while reducing the aerobic plate counts significantly [147]. Higher redness value, less protein degradation, and less residual nitrite level were exhibited when pork loin was cured with ascorbic acids compared to the control treatments [148]. Furthermore, Carpenter et al. [149] reported a lower salmonella population on pork belly treated with $2 \%$ of lactic or acetic acid spray washing, which minimized the tendency of a later growth rate of pathogens. A recent study assessed the antimicrobial effect of organic acids $(1,2$ and $3 \%$ of acetic, lactic, and citric acids) against L. monocytogenes, E. coli, S. Enteritidis, Y. enterocolitica, and $C$. jejuni in pork meat. However, the most effective OA was lactic acid, followed by acetic and citric acid, respectively [150]. González Sánchez [151] evaluated the antimicrobial capacity of formic acid (1.5\%) and peroxyacetic acid (400 ppm). They reported that acid spray treatment effectively influenced the reduction of Salmonella enterica counts in meat pork after $24 \mathrm{~h}$ at a lower temperature $\left(4^{\circ} \mathrm{C}\right)$.

Gonzalez-Fandos et al. [152] evaluated the decontaminating ability of acetic, citric, and fumaric acids, and potassium sorbate to decrease Campylobacter jejuni on chicken legs. The analyzed data showed the lowest Pseudomonas counts, lowest Enterobacterales counts, and highest $C$. jejuni reductions in treatments, consisting of $2 \%$ fumaric, $2 \%$ fumaric, or $2 \%$ acetic, and $2 \%$ citric acid, respectively. Interestingly, the application of $0.5 \%$ microencapsulated OAs (citric and sorbic) with essential oil resulted in less intramuscular fat, lower saturated/polyunsaturated fatty acids ratio, reduced TBARS value, zero contamination of Listeria spp., Campylobacter spp., and Clostridium spp. and increased meat color values than the control treatment [153]. A lower TBARS value influenced the lower lipid oxidation in meat, and prevented the degradation of unsaturated fatty acids, and converted oxymyoglobin to metmyoglobin. Otherwise, the high lipid oxidation process led 
to the generation of free radicals and rapid meat quality deterioration [154]. Therefore, OA treatments for meat preservation will improve qualitative characteristics in both meat pork and broilers.

\section{Potential concerns regarding OAs utilization}

Pathogenic microbial activities encompass a broad range of survival mechanisms that facilitate the multiplication and survival by evading their host defense system. Although OAs supplementation has a favorable impact on pigs and broiler production through the biological defense system, bacterial resistance should be considered. Recent studies revealed the specific developed mechanisms of Escherichia coli [142] and Salmonella enterica $[155,156]$. Some genes, including wecA (rfe), waaG (rfaG), fcl (Fucose, FX-like), and wecB (rffE), can control the manipulation of acid tolerance response. The degradation of surface O-polysaccharide plus enterobacterial common antigen (ECA) and O-polysaccharide occur because of those mutations, which are acting as reinforcement agents in Salmonella spp and E. coli groups against the OAs. This adaption process consists of two mechanisms: (1) transient adaptation and (2) pre-challenge adaptation, which occurs specifically in lower $\mathrm{pH}$ ranges [157,158,159]. Despite minimizing the cost of production and the requirement of specific awareness, encapsulated OAs utilization has gained less popularity in the commercial livestock sector except for experimental studies. Hume et al. [160] reported that most unprotected propionic acid did not reach the crop, proventiculus, gizzard, and rest of the small intestines. Because the crop acts as a primary site for salmonella colonization, the movements of OAs to the lower GIT tract should be ensured by incorporating novel technological methods. Conner and Kotrola [161] reported that E.coli could survive under $\mathrm{pH} \geq 4.0$ and below $4.0^{\circ} \mathrm{C}$ for up to 56 days. On the other hand, the prevalence is affected by the temperature and type of the acidifier. OAs, being SCFA, have lower $\mathrm{pH}$ levels in the GI tract, consequently reducing the livability of pathogenic bacteria at the cellular level. Nevertheless, $\mathrm{pH}$-independent tolerance is also possible. Higher resistance to $S$. typhimurium was observed when the animals were exposed to higher SCFA concentrations, which produced a lower pH environment in the GI tract [162]. Kwon et al. [163] reported that higher SCFA concentrations in the large intestines cause the cross-resistance of S. typhimurium $14028 \mathrm{~S}$ to other stressors, including extreme $\mathrm{pH}$ level and $20 \mathrm{mM} \mathrm{H}_{2} \mathrm{O}_{2}$. Dickenes et al. [164] and Dickenes and Whittemore [165] reported that the appearance and texture quality of broiler meat was influenced adversely by acetic acid dipping. Although most OA combinations were favorably associated with nutrient digestibility, Garber and Sauer [166] reported lower $\mathrm{CP}$ and amino acid digestibility in the pig ileum. Another considerable effect of supplementation of OAs is the reduction of lactic acid synthesis and LAB population in the GI tract. Thompsan and Hinton [167] reported the interaction of formic and propionic acid inclusion on lower lactic acid production in the crop. Thus, the concentrations and interactions among each $\mathrm{OA}$ combination will require further molecular based studies.

\section{Conclusion}

The supplementation of organic acids has significant effects on the growth performance and digestion of nutrients by modulating the gut environment of both swine and broilers. In particular, some OAs significantly developed the gut physiology by increasing the villus height: width ratio and surface area of the duodenum, jejunum, and ileum of swine and broilers. Previous studies reported that protective OAs supplementation is effective and safe for monogastric animal diets because they act on the exact stimulus while delaying quick movement in the GI track. On the other hand, to benefit from the effectiveness of OAs, the inclusion dosage, rearing environment, nutrient composition, growth phase, and health status of animals need to be considered. The lack of consistency in exhibiting the benefits of dietary inclusion of OAs on meat quality parameters, sensory attributes, and storage safety should be evaluated further. The chemical mechanisms of OAs in animal diet and synergism effects are not completely understood. Therefore, it is impossible 
to recommend a specific combination of OAs and concentrations that will positively affect the swine and broiler production parameters and meat quality traits. On the other hand, the application of OAs treatments on meat product preservation has positive impacts on the quality improvements. Further scientific exploration will be needed to unravel the exact modes of action in different parts of the GI tract and based on the inclusion concentration. Once more knowledge comes available, promising feeding strategies can be implemented by incorporating various organic acid formulas into the animal diet.

Funding: This research received no external funding

Institutional Review Board Statement: Not applicable

Informed Consent Statement: Not applicable

Data Availability Statement: Not Applicable

Acknowledgments: Industrial Technology Innovation Business Development and Demonstration of Renewable Energy Mixed-Use System for the Livestock Industry, Korea and the Cooperative Research Program for Agriculture Science \& Technology Development Rural Development Administration, Republic of Korea.

Conflicts of Interest: The authors declare no conflict of interest.

\section{References}

1. Nguyen, D.H.; Kim, I.H. Protected Organic Acids Improved Growth Performance, Nutrient Digestibility, and Decreased Gas Emission in Broilers. Animals 2020, 10, 416, doi:10.3390/ani10030416.

2. Tugnoli, B.; Giovagnoni, G.; Piva, A.; Grilli, E. From acidifiers to intestinal health enhancers: How organic acids can improve growth efficiency of pigs. Animals, 2020, 10(1), 134.

3. Kim, Y.Y.; Kil, D.Y.; Oh, H.K.; Han, I.K. Acidifier as an Alternative Material to Antibiotics in Animal Feed. Asian Australas. J. Anim. Sci 2005, 18, 1048-1060, doi:10.5713/ajas.2005.1048.

4. Kil, D.Y.; Piao, L.G.; Long, H.F.; Lim, J.S.; Yun, M.S.; Kong, C.S.; Ju, W.S.; Lee, H.B.; Kim, Y.Y. Effects of Organic or Inorganic Acid Supplementation on Growth Performance, Nutrient Digestibility and White Blood Cell Counts in Weanling Pigs. Asian Australas. J. Anim. Sci 2005, 19, 252-261, doi:10.5713/ajas.2006.252.

5. Mroz, Z.; Reese, D.E.; Øverland, M.; van Diepen, J.T.M.; Kogut, J. The Effects of Potassium Diformate and Its Molecular Constituents on the Apparent Ileal and Fecal Digestibility and Retention of Nutrients in Growing-Finishing Pigs. J Anim Sci 2002, 80, 681-690, doi:10.2527/2002.803681x.

6. Partanen, K.H.; Mroz, Z. Organic acids for performance enhancement in pig diets. Nutr. Res. Rev. 1999, 12, 117-145.

7. Spratt, C.D. Effect of Mould Inhibitor Treated High Moisture Corn on Performance of Poultry. MSc Thesis, University of Guelph, Guelph, ON, Canada, 1985.

8. Luise, D.; Motta, V.; Salvarani, C.; Chiappelli, M.; Fusco, L.; Bertocchi, M.; Mazzoni, M.; Maiorano, G.; Costa, L.N.; Van Milgen, J.; et al. Long-Term Administration of Formic Acid to Weaners: Influence on Intestinal Microbiota, Immunity Parameters and Growth Performance. Anim Feed Sci Tech 2017, 232, 160-168, doi:10.1016/j.anifeedsci.2017.06.015.

9. Ndelekwute, E.K.; Assam, E.D.; Ekere, P.C. Effect of organic acid treated diets on growth, apparent nutrient digestibility and faecal moisture of broiler chickens. Nigerian J. Anim. Sci. 2016, 43, 218-223. 
10. Huang, C.; Song, P.; Fan, P.; Hou, C.; Thacker, P.; Ma, X. Dietary Sodium Butyrate Decreases Postweaning Diarrhea by Modulating Intestinal Permeability and Changing the Bacterial Communities in Weaned Piglets. J Nutr 2015, 145, 2774-2780, doi:10.3945/jn.115.217406.

11. Fascina, V.B.; Sartori, J.R.; Gonzales, E.; Carvalho, F.B. de; Souza, I.M.G.P. de; Polycarpo, G. do V.; Stradiotti, A.C.; Pelícia, V.C. Phytogenic Additives and Organic Acids in Broiler Chicken Diets. R. Bras. Zootec. 2012, 41, 2189-2197, doi:10.1590/S1516-35982012001000008.

12. Tsiloyiannis, V.K.; Kyriakis, S.C.; Vlemmas, J.; Sarris, K.; The effect of organic acids on the control of porcine postweaning diarrhea. Res Vet Sci. 2001, 70(3), 287-293

13. Dittoe, D.K.; Ricke, S.C.; Kiess, A.S. Organic acids and potential for modifying the avian gastrointestinal tract and reducing pathogens and disease. Front vet sci 2018, 5,.216.

14. Yang, X.; Xin, H.; Yang, C.; Yang, X. Impact of Essential Oils and Organic Acids on the Growth Performance, Digestive Functions and Immunity of Broiler Chickens. Anim Nutr 2018, 4, 388-393, doi:10.1016/j.aninu.2018.04.005.

15. Pearlin, B.V.; Muthuvel, S.; Govidasamy, P.; Villavan, M.; Alagawany, M.; Ragab Farag, M.; Dhama, K.; Gopi, M. Role of acidifiers in livestock nutrition and health: A review. J anim physiol anim nutr 2020, 104(2), 558-569.

16. Shahidi, S.; Yahyavi, M.; Zare, D.N. Influence of Dietary Organic Acids Supplementation on Reproductive Performance of Freshwater Angelfish (Pterophyllum Scalare). Global Vet. 2014, 13,373-377

17. Ravindran, V.; Kornegay, E.T. Acidification of Weaner Pig Diets: A Review. J. Sci. Food Agric. 1993, 62, 313-322, doi:10.1002/jsfa.2740620402.

18. Nguyen, D.H.; Seok, W.J.; Kim, I.H. Organic Acids Mixture as a Dietary Additive for Pigs-A Review. Animals 2020, 10, 952, doi:10.3390/ani10060952.

19. de Lange, C.F.M.; Pluske, J.; Gong, J.; Nyachoti, C.M. Strategic Use of Feed Ingredients and Feed Additives to Stimulate Gut Health and Development in Young Pigs. Livest Sci 2010, 134, 124-134, doi:10.1016/j.livsci.2010.06.117.

20. Boling, S.D.; Webel, D.M.; Mavromichalis, I.; Parsons, C.M.; Baker, D.H. The Effects of Citric Acid on Phytate-Phosphorus Utilization in Young Chicks and Pigs. J Anim Sci 2000, 78, 682, doi:10.2527/2000.783682x.

21. Jongbloed, A.W.; Mroz, Z.; van der Weij-Jongbloed, R.; Kemme, P.A. The Effects of Microbial Phytase, Organic Acids and Their Interaction in Diets for Growing Pigs. Livest Prod Sci 2000, 67, 113-122, doi:10.1016/S0301-6226(00)00179-2.

22. Kirchegessner, M.; Roth, F.X. Fumaric acid as a fed additive in pig nutrition. Pig News Info. 1982; 3: 259

23. Ao, T. Exogenous enzymes and organic acids in the nutrition of broiler chicks: effects on growth performance and in vitro and in vivo digestion. PhD Thesis, University of Kentucky. 2005

24. Afsharmanesh, M.; Pourreza, J. Effects of calcium, citric acid, ascorbic acid, vitamin D3 on the efficacy of microbial phytase in broiler starters fed wheat-based diets I. Performance, bone mineralization and ileal digestibility. Int. J. Poult. Sci. 2005, 4, 418-424

25. Adil, S.; Banday, T.; Bhat, G.A.; Mir, M.S.; Rehman, M. Effect of Dietary Supplementation of Organic Acids on Performance, Intestinal Histomorphology, and Serum Biochemistry of Broiler Chicken. Veterinary Medicine International 2010, 2010, 1-7, doi:10.4061/2010/479485.

26. Van Der Sluis, W. Water quality is important but often overestimated. World Poult, 2002, 18(5), 26-32.

27. Omogbenigun, F.O.; Nyachoti, C.M.; Slominski, B.A. The Effect of Supplementing Microbial Phytase and Organic Acids to a Corn-Soybean Based Diet Fed to Early-Weaned Pigs. J Anim Sci 2003, 81, 1806-1813, doi:10.2527/2003.8171806x. 
28. Dittoe, D.K.; Ricke, S.C.; Kiess, A.S. Organic Acids and Potential for Modifying the Avian Gastrointestinal Tract and Reducing Pathogens and Disease. Front. Vet. Sci. 2018, 5, 216, doi:10.3389/fvets.2018.00216.

300

29. Mroz, Z.; Koopmans, S. J.; Bannink, A.; Partanen, K.; Krasucki, W.; Overland, M.; Radcliffe, S. Carboxylic acids as bio regulators and gut growth promoters in non-ruminants. In Mosenthin, R.; Zentek, J.; Zebrowska, T (Eds). Biology of nutrition in growing animals. Elsevier, Edinburgh, UK: 2006, volume 3, pp. 81-133

30. Stratford, M.; Eklund, T. Organic acids and esters. In Food Preservatives; Springer: Boston, MA, USA, 2003, pp. 4884.

31. Suiryanrayna, M.V.A.N.; Ramana, J.V. A Review of the Effects of Dietary Organic Acids Fed to Swine. J Animal Sci Biotechnol 2015, 6, 45, doi:10.1186/s40104-015-0042-z.

32. Dibner, J.; Buttin, P. Use of organic acids as a model to study the impact of gut microflora on nutrition and metabolism. J Appl Poult Sci. 2002a, 11,453-463. https://doi.org/10.1093/ japr/11.4.453

33. Dibner, J. J.; Buttin, P. Use of organic acids as a model to study the impact of gut microflora on nutrition and metabolism. J Appl Poult Res, 2002b, 11, 453-463. https://doi.org/10.1093/ japr/11.4.453

34. Luckstadt, C.; Mellor, S. The use of organic acids in animal nutrition, with special focus on dietary potassium diformate under European and Austral-Asian conditions. Recent Adv Anim Nutr Aust, 2011,18, 123-130.

35. Gauthier, R. Intestinal health, the key to productivity - the case of organic acids. Precongreso Cientifico Avicola IASA XXVII convencion ANECA-WPDC, Puerto Vallarta, Jal, Mexico, 2002

36. Hirshfield, I.N.; Terzulli, S.; O’Byrne, C. Weak Organic Acids: A Panoply of Effects on Bacteria. Science Progress 2003, 86, 245-270, doi:10.3184/003685003783238626.

37. Ng, W.-K.; Koh, C.-B. The Utilization and Mode of Action of Organic Acids in the Feeds of Cultured Aquatic Animals. Rev Aquacult 2017, 9, 342-368, doi:10.1111/raq.12141.

38. Sk`rivanová, E.; Marounek, M.; Benda, V.; B`rezina, P. Susceptibility of Escherichia coli, Salmonella sp and Clostridium perfringens to organic acids and monolaurin. Vet. Med. Praha 2006, 51, 81-88.

39. Biagi, G.; Piva, A.; Hill, T.; Schneider, D.K.; Crenshaw, T.D. Low buffering capacity diets with added organic acids as substitute for antibiotics in diets for weaned pigs. In: Ball R, editor. Proceedings of the 9th International Symposium on digestive Physiology in pigs. Edmonton, Banff, Alberta, Canada: University of Alberta, Department of Agriculture, Food and Nutritional Science; 2003. pp. 217-219.

40. Pinheiro, V.; Mourao, J.L., Alves, A.; Rodrigues, M.; Saavedra, M.J. Effect of Zinc bacitracin on the performance,digestibility and caecal development of growing rabbits. In: Proceedings of the 8th world rabbit congress, Puebla, Mexico, 2004, pp 942-947.

41. Van Immerseel, F.; Russell, J.B.; Flythe, M.D.; Gantois, I.; Timbermont, L.; Pasmans, F.; Haesebrouck, F.; Ducatelle, R. The Use of Organic Acids to Combat Salmonella in Poultry: A Mechanistic Explanation of the Efficacy. Avian Pathol 2006, 35, 182-188, doi:10.1080/03079450600711045.

42. Fernández-Rubio, C.; Ordóñez, C.; Abad-González, J.; Garcia-Gallego, A.; Honrubia, M.P.; Mallo, J.J.; Balaña-Fouce, R. Butyric Acid-Based Feed Additives Help Protect Broiler Chickens from Salmonella Enteritidis Infection. Poultry Science 2009, 88, 943-948, doi:10.3382/ps.2008-00484.

43. Grilli, E.; Piva, A. Organic acids and their role in reduce foodborne pathogens in food animals. In On-Farm Strategies to Control Foodborne Pathogens; Callaway, T.R., Edrington, T.S., Eds.; Nova Science Pub. Inc.: Hauppauge, NY, USA, 2012; pp. 183-210 
44. Grilli, E.; Vitari, F.; Domeneghini, C.; Palmonari, A.; Tosi, G.; Fantinati, P.; Massi, P.; Piva, A. Development of a feed additive to reduce caecal Campylobacter jejuni in broilers at slaughter age: From in vitro to in vivo, a proof of concept. J. Appl. Microbiol. 2013, 114, 308-317.

45. Grilli, E.; Tugnoli, B.; Passey, J.L.; Stahl, C.H.; Piva, A.; Moeser, A.J. Impact of dietary organic acids and botanicals on intestinal integrity and inflammation in weaned pigs. BMC Vet. Res. 2015, 11, 96-105.

46. Mohammadi Gheisar, M.; Hosseindoust, A.; Kim, I.H. Evaluating the Effect of Microencapsulated Blends of Organic Acids and Essential Oils in Broiler Chickens Diet. J Appl Poultry Res. 2015, 24, 511-519, doi:10.3382/japr/pfv063.

47. Gheisari, A.A.; Heidari, M.; Kermanshahi, R.K.; Togani, M.; Saraeian, S. Effect of dietary supplementation of protected organic acids on ileal microflora and protein digestibility in broiler chickens. In Proceedings of the 16th European Symposium on Poultry Nutrition, Strasbourg, France, 26-30 August 2007; pp. 519-522

48. Stamilla, A.; Russo, N.; Messina, A.; Spadaro, C.; Natalello, A.; Caggia, C.; Randazzo, C.L.; Lanza, M. Effects of Microencapsulated Blend of Organic Acids and Essential Oils as a Feed Additive on Quality of Chicken Breast Meat. Animals 2020, 10, 640. https://doi.org/10.3390/ani10040640

49. Piva, A.; Pizzamiglio, V.; Morlacchini, M.; Tedeschi, M.; Piva, G. Lipid microencapsulation allows slow release of organic acids and natural identical flavors along the swine intestine. J. Anim. Sci. 2007, 85, 486-493.

50. Huyghebaert, G.; Ducatelle, R.; Immerseel, F.V. An Update on Alternatives to Antimicrobial Growth Promoters for Broilers. The Veterinary Journal 2011, 187, 182-188, doi:10.1016/j.tvjl.2010.03.003.

51. Tsai, C.C.; Hsih, H.Y.; Chiu, H.H.; Lai, Y.Y.; Liu, J.H.; Yu, B.; Tsen, H.Y. Antagonistic Activity against Salmonella Infection in Vitro and in Vivo for Two Lactobacillus Strains from Swine and Poultry. International Journal of Food Microbiology 2005, 102, 185-194, doi:10.1016/j.ijfoodmicro.2004.12.014.

52. Baurhoo, B.; Letellier, A.; Zhao, X.; Ruiz-Feria, C.A. Cecal Populations of Lactobacilli and Bifidobacteria and Escherichia Coli Populations After In Vivo Escherichia Coli Challenge in Birds Fed Diets with Purified Lignin or Mannanoligosaccharides. Poul Sci J. 2007, 86, 2509-2516, doi:10.3382/ps.2007-00136.

53. Biggs, P.; Parsons, C.M. The Effects of Grobiotic-P on Growth Performance, Nutrient Digestibilities, and Cecal Microbial Populations in Young Chicks. Poul Sci J. 2008, 87, 1796-1803, doi:10.3382/ps.2007-00450.

54. Papatsiros, V. Alternatives to Antibiotics for Farm Animals. CAB Reviews 2013, 8, doi:10.1079/PAVSNNR20138032.

55. Fuller R. Probiotics: their development and use. In: Fuller R, Heidt PJ, Rusch V, van der Waaj, editors. Old Herborn University Seminar Monograph 8. Herborn-Dill: Institute for Microbiology and Biochemistry (1995). p. 1-8.

56. Huyghebaert, G.; Ducatelle, R.; Immerseel, F.V. An Update on Alternatives to Antimicrobial Growth Promoters for Broilers. The Veterinary Journal 2011, 187, 182-188, doi:10.1016/j.tvjl.2010.03.003.

57. Farooq, U.; Mohsin, M.; Liu, X.; Zhang, H. Enhancement of Short Chain Fatty Acid Production from Millet Fibres by Pure Cultures of Probiotic Fermentation. Trop. J. Pharm Res 2013, 12, 189-194, doi:10.4314/tjpr.v12i2.9.

58. Rehman, H.; Hellweg, P.; Taras, D.; Zentek, J. Effects of Dietary Inulin on the Intestinal Short Chain Fatty Acids and Microbial Ecology in Broiler Chickens as Revealed by Denaturing Gradient Gel Electrophoresis. Poul Sci J. 2008, 87, 783-789, doi:10.3382/ps.2007-00271.

59. Walsh, M.C.; Sholly, D.M.; Hinson, R.B.; Saddoris, K.L.; Sutton, A.L.; Radcliffe, J.S.; Odgaard, R.; Murphy, J.; Richert, B.T. Effects of water and diet acidification with and without antibiotics on weanling pig growth and microbial shedding. J. Anim. Sci. 2007, 85, 1799-1808

60. Kathrin, B., 2009. Benzoic acid as feed additive in pig nutrition: Effects of diet composition on performance, digestion and ecological aspects (Doctoral thesis). ETH Zurich, https://doi.org/10.3929/ethz-a-005834561 
61. Falkowski, J.F.; Aherne, F.X. Fumaric and Citric Acid as Feed Additives in Starter Pig Nutrition. J Anim Sci. 1984, 58, 935-938, doi:10.2527/jas1984.584935x.

379

62. Kuang, Y.; Wang, Y.; Zhang, Y.; Song, Y.; Zhang, X.; Lin, Y.; Che, L.; Xu, S.; Wu, D.; Xue, B.; et al. Effects of dietary combinations of organic acids and medium chain fatty acids as a replacement of zinc oxide on growth, digestibility and immunity of weaned pigs. Anim. Feed Sci. Technol. 2015, 208, 145-157

63. Grecco, H.A.T.; Amorim, A.B.; Saleh, M.A.D.; Tse, M.L.P.; Telles, F.G.; Miassi, G.M.; Pimenta, G.M.; Berto, D.A. Evaluation of growth performance and gastro-intestinal parameters on the response of weaned piglets to dietary organic acids. An. Acad. Bras. Ciências 2018, 90, 401-414

64. Risley, C.R.; Kornegay, E.T.; Lindemann, M.D.; Wood, C.M.; Eigel, W.N. Effect of feeding organic acids on selected intestinal content measurements at varying times post weaning in pigs. J. Anim. Sci. 1992, 70, 196-206

65. Htoo, J.K.; Molares, J. Effects of dietary supplementation with two potassium formate sources on performance of 8to $22-\mathrm{kg}$ pigs. J. Anim. Sci. 2012, 90, 346-349

66. Canibe, N.; Højberg, O.; Højsgaard, S.; Jensen, B.B. Feed physical form and formic acid addition to the feed affect the gastrointestinal ecology and growth performance of growing pigs. J. Anim. Sci. 2005, 83, 1287-1302

67. Partanen, K.; Siljander-Rasi, H.; Alaviuhkola, T.; Suomi, K.; Fossi, M. Performance of growing-finishing pigs fed mediumor high-fibre diets supplemented with avilamycin, formic acid or formic acid-sorbate blend. Livest. Prod. Sci. 2002, 73, 139-152

68. Yang, C.; Zhang, L.; Cao, G.; Feng, J.; Yue, M.; Xu, Y.; Dai, B.; Han, Q.; Guo, X. Effects of Dietary Supplementation with Essential Oils and Organic Acids on the Growth Performance, Immune System, Fecal Volatile Fatty Acids, and Microflora Community in Weaned Piglets. J Anim Sci. 2019, 97, 133-143, doi:10.1093/jas/sky426.

69. Adil, S.; Banday, T.; Ahmad Bhat, G.; Salahuddin, M.; Raquib, M.; Shanaz, S. Response of Broiler Chicken to Dietary Supplementation of Organic Acids. j. cent. eur. agric. 2011, 12, 498-508, doi:10.5513/JCEA01/12.3.947.

70. Hassan, H.M.A.; Mohamed, M.A.; Youssef, A.W; Hassan, E.R. Effect of using organic acids to substitute antibiotic growth promoters on performance and intestinal microflora of broilers. Asian-Austral J Anim Sci. 2010, 23(10), 13481353.

71. Kamal, A.M.; Ragaa, N.M. Effect of dietary supplementation of organic acids on performance and serum biochemistry of broiler chicken. Nature and Science. 2014, 12(2), 38-45

72. Ghazala, A.A.; Atta, A.M.; Elkloub, K.; Mustafa, M.E.L.; Shata, R.F.H. Effect of dietary supplementation of organic acids on performance, nutrients digestibility and health of broiler chicks. Int J Poultry Sci. 2011, 10(3), 176-184

73. Yang, X., Liu, Y., Yan, F., Yang, C. and Yang, X. Effects of encapsulated organic acids and essential oils on intestinal barrier, microbial count, and bacterial metabolites in broiler chickens. Poultry science. 2019, 98(7), 2858-2865.

74. Yang, Y.; Lee, K.Y.; Kim, I.H. Effects of Dietary Protected Organic Acids on Growth Performance, Nutrient Digestibility, Fecal Microflora, Diarrhea Score, and Fecal Gas Emission in Weanling Pigs. Can. J. Anim. Sci. 2019, 99, 514-520, doi:10.1139/cjas-2018-0159.

75. Upadhaya, S.D.; Lee, K.Y.; Kim, I.H. Effect of Protected Organic Acid Blends on Growth Performance, Nutrient Digestibility and Faecal Micro Flora in Growing Pigs. Journal of Applied Animal Research 2016, 44, 238-242, doi:10.1080/09712119.2015.1031775.

76. Xu, Y.T.; Liu, Li.; Long, S.F.; Pan, L.; Piao, X.S. Effect of Organic Acids and Essential Oils on Performance, Intestinal Health and Digestive Enzyme Activities of Weaned Pigs. Animal Feed Science and Technology 2018, 235, 110-119, doi:10.1016/j.anifeedsci.2017.10.012. 
77. Namkung, H.; Li J. Gong, M.; Yu, H.; Cottrill, M.; de Lange, C.F.M. Impact of Feeding Blends of Organic Acids and Herbal Extracts on Growth Performance, Gut Microbiota and Digestive Function in Newly Weaned Pigs. Can. J. Anim. Sci. 2004, 84, 697-704, doi:10.4141/A04-005.

78. Wei, X.; Bottoms, K.A.; Stein, H.H.; Blavi, L.; Bradley, C.L.; Bergstrom, J.; Knapp, J.; Story, R.; Maxwell, C.; Tsai, T.; et al. Dietary Organic Acids Modulate Gut Microbiota and Improve Growth Performance of Nursery Pigs. Microorganisms 2021, 9, 110, doi:10.3390/microorganisms9010110.

79. Kluge, H.; Broz, J.; Eder, K. Effect of Benzoic Acid on Growth Performance, Nutrient Digestibility, Nitrogen Balance, Gastrointestinal Microflora and Parameters of Microbial Metabolism in Piglets. J Anim Physiol Anim Nutr 2006, 90, 316-324, doi:10.1111/j.1439-0396.2005.00604.x.

80. Li, Z.; Yi, G.; Yin, J.; Sun, P.; Li, D.; Knight, C. Effects of Organic Acids on Growth Performance, Gastrointestinal PH, Intestinal Microbial Populations and Immune Responses of Weaned Pigs. Asian Australas. J. Anim. Sci 2008, 21, 252261, doi:10.5713/ajas.2008.70089.

81. Upadhaya, S.; Lee, K.; Kim, I. Influence of Protected Organic Acid Blends and Diets with Different Nutrient Densities on Growth Performance, Nutrient Digestibility and Faecal Noxious Gas Emission in Growing Pigs. Veterinarni Medicina 2014, 59, 491-497, doi:10.17221/7779-VETMED.

82. Øverland, M., Kjos, N.P., Borg, M., Skjerve, E. and Sørum, H. Organic acids in diets for entire male pigs: Effect on skatole level, microbiota in digesta, and growth performance. Livest Sci. 2008, 115, 169-178.

83. Papatsiros, V.; Tassis, P.; Tzika, E.; Papaioannou, D.; Petridou, E.; Alexopoulos, C.; Kyriakis, S. Effect of Benzoic Acid and Combination of Benzoic Acid with a Probiotic Containing Bacillus Cereus Var. Toyoi in Weaned Pig Nutrition. Polish Journal of Veterinary Sciences 2011, 14, doi:10.2478/v10181-011-0017-8.

84. Luise, D.; Motta, V.; Salvarani, C.; Chiappelli, M.; Fusco, L.; Bertocchi, M.; Mazzoni, M.; Maiorano, G.; Costa, L.N.; Van Milgen, J.; et al. Long-Term Administration of Formic Acid to Weaners: Influence on Intestinal Microbiota, Immunity Parameters and Growth Performance. Animal Feed Science and Technology 2017, 232, 160-168, doi:10.1016/j.anifeedsci.2017.06.015.

85. Saleem, K.; Saima; Rahman, A.; Pasha, T.N.; Mahmud, A.; Hayat, Z. Effects of Dietary Organic Acids on Performance, Cecal Microbiota, and Gut Morphology in Broilers. Trop Anim Health Prod 2020, 52, 3589-3596, doi:10.1007/s11250020-02396-2.

86. Metwally Ali, A.; Mostafa El Agrab, H.; Mamdouh Hamoud, M.; Mohamed Gamal, A.; Refat Mousa, M.; Abo Elsoud Nasr, S.; Ahmed Hassan El Shater, M.; Elsaeed Laban, S.; Kamel Zahran, O.; Mohamed Ali, M. Effect of Acidified Drinking Water by Organic Acids on Broiler Performance and Gut Health. AAVS 2020, 8, doi:10.17582/journal.aavs/2020/8.12.1301.1309.

87. Stamilla, A.; Messina, A.; Sallemi, S.; Condorelli, L.; Antoci, F.; Puleio, R.; Loria, G.R.; Cascone, G.; Lanza, M. Effects of Microencapsulated Blends of Organics Acids (OA) and Essential Oils (EO) as a Feed Additive for Broiler Chicken. A Focus on Growth Performance, Gut Morphology and Microbiology. Animals 2020, 10, 442, doi:10.3390/ani10030442.

88. Goh, C.H.; Loh, T.C.; Foo, H.L.; Nobilly, F. Fecal Microbial Population and Growth in Broiler Fed Organic Acids and Palm Fat-Composed Diet. Trop. Anim. Sci. J. 2020, 43, 151-157, doi:10.5398/tasj.2020.43.2.151.

89. Dai, D.; Qiu, K.; Zhang, H.; Wu, S.; Han, Y.; Wu, Y.; Qi, G.; Wang, J. Organic Acids as Alternatives for Antibiotic Growth Promoters Alter the Intestinal Structure and Microbiota and Improve the Growth Performance in Broilers. Front. Microbiol. 2021, 11, 618144, doi:10.3389/fmicb.2020.618144.

90. Sabour, S.; Tabeidian, S.A.; Sadeghi, G. Dietary Organic Acid and Fiber Sources Affect Performance, Intestinal Morphology, Immune Responses and Gut Microflora in Broilers. Animal Nutrition 2019, 5, 156-162, doi:10.1016/j.aninu.2018.07.004. 
91. Fathi, R., Samadi, M.S., Qotbi, A.A., Seidavi, A. and Marín, A.L.M. Effects of feed supplementation with increasing levels of organic acids on growth performance, carcass traits, gut microbiota and $\mathrm{pH}$, plasma metabolites, and immune response of broilers. Anim Sci Pap Rep. 2016, 34,195-206.

92. Panda, A.K.; Rao, S.V.R.; Raju, M.V.L.N.; Sunder, G.S. Effect of Butyric Acid on Performance, Gastrointestinal Tract Health and Carcass Characteristics in Broiler Chickens. Asian Australas. J. Anim. Sci 2009, 22, 1026-1031, doi:10.5713/ajas.2009.80298.

93. Sultan, A., Ullah, T., Khan, S. and Khan, R.U. Effect of organic acid supplementation on the performance and ileal microflora of broiler during finishing period. Pak J Zool. 2015, 47. 32-38

94. Panda, A.K., Raju, M.V.L.N., Rao, S.R., Sunder, G.S. and Reddy, M.R. Effect of graded levels of formic acid on gut microflora count, serum biochemical parameters, performance and carcass yield of broiler chickens. Indian J Anim Sci. $2009,79,1165-1168$.

95. Adil, S.; Banday, T.; Bhat, G.A.; Mir, M.S.; Rehman, M. Effect of Dietary Supplementation of Organic Acids on Performance, Intestinal Histomorphology, and Serum Biochemistry of Broiler Chicken. Veterinary Medicine International 2010, 2010, 1-7, doi:10.4061/2010/479485.

96. Lakshmi, K.V.; Sunder, G.S. Supplementation of Propionic Acid (PA), Butyric Acid (BA) or Antibiotic (AB) in diets and their influence on broiler performance, carcass parameters and immune response. IJSR. 2015, 4(3),1002-1006.

97. Upadhaya, S.D.; Lee, K.Y.; Kim, I.H. Protected Organic Acid Blends as an Alternative to Antibiotics in Finishing Pigs. Asian Australas. J. Anim. Sci 2014, 27, 1600-1607, doi:10.5713/ajas.2014.14356.

98. Rosiñski, S.; Grigorescu, G.; Lewiñska, D.; Ritzén, L.G.; Viernstein, H.; Teunou, E.; Poncelet, D.; Zhang, Z.; Fan, X.; Serp, D.; et al. Characterization of Microcapsules: Recommended Methods Based on Round-Robin Testing. Journal of Microencapsulation 2002, 19, 641-659, doi:10.1080/02652040210142533.

99. Hossain, M.M.; Jayaraman, B.; Kim, S.C.; Lee, K.Y.; Kim, I.H.; Nyachoti, C.M. Effects of a matrix-coated organic acids and medium-chain fatty acids blend on performance, and in vitro fecal noxious gas emissions in growing pigs fed infeed antibiotic-free diets. Can. J. Anim. Sci. 2018, 98, 433-442

100. Liu, S.T.; Hou, W.X.; Cheng, S.Y.; Shi, B.M.; Shan, A.S. Effects of Dietary Citric Acid on Performance, Digestibility of Calcium and Phosphorus, Milk Composition and Immunoglobulin in Sows during Late Gestation and Lactation. Animal Feed Science and Technology 2014, 191, 67-75, doi:10.1016/j.anifeedsci.2014.01.017.

101. Yang, Y.; Lee, K.Y.; Kim, I.H. Effects of Dietary Protected Organic Acids on Growth Performance, Nutrient Digestibility, Fecal Microflora, Diarrhea Score, and Fecal Gas Emission in Weanling Pigs. Can. J. Anim. Sci. 2019, 99, 514-520, doi:10.1139/cjas-2018-0159.

102. Sauer, W.; Cervantes, M.; Yanez, J.; Araiza, B.; Murdoch, G.; Morales, A.; Zijlstra, R.T. Effect of Dietary Inclusion of Benzoic Acid on Mineral Balance in Growing Pigs. Livestock Science 2009, 122, 162-168, doi:10.1016/j.livsci.2008.08.008.

103. Bühler, K.; Liesegang, A.; Bucher, B.; Wenk, C.; Broz, J. Influence of Benzoic Acid and Phytase in Low-Phosphorus Diets on Bone Characteristics in Growing-Finishing Pigs1. Journal of Animal Science 2010, 88, 3363-3371, doi:10.2527/jas.2009-1940.

104. Guggenbuhl, P.; Séon, A.; Quintana, A.P.; Nunes, C.S. Effects of Dietary Supplementation with Benzoic Acid (VevoVitall@) on the Zootechnical Performance, the Gastrointestinal Microflora and the Ileal Digestibility of the Young Pig. Livestock Science 2007, 108, 218-221, doi:10.1016/j.livsci.2007.01.068.

105. Kluge, H.; Broz, J.; Eder, K. Effects of Dietary Benzoic Acid on Urinary PH and Nutrient Digestibility in Lactating Sows. Livestock Science 2010, 134, 119-121, doi:10.1016/j.livsci.2010.06.116. 
106. Hernández, F.; García, V.; Madrid, J.; Orengo, J.; Catalá, P.; Megías, M.D. Effect of Formic Acid on Performance, Digestibility, Intestinal Histomorphology and Plasma Metabolite Levels of Broiler Chickens. British Poultry Science 2006, 47, 50-56, doi:10.1080/00071660500475574.

107. García, V.; Catalá-Gregori, P.; Hernández, F.; Megías, M.D.; Madrid, J. Effect of Formic Acid and Plant Extracts on Growth, Nutrient Digestibility, Intestine Mucosa Morphology, and Meat Yield of Broilers. Journal of Applied Poultry Research 2007, 16, 555-562, doi:10.3382/japr.2006-00116.

108. Ao, T.; Cantor, A.H.; Pescatore, A.J.; Ford, M.J.; Pierce, J.L.; Dawson, K.A. Effect of Enzyme Supplementation and Acidification of Diets on Nutrient Digestibility and Growth Performance of Broiler Chicks. Poultry Science 2009, 88, 111-117, doi:10.3382/ps.2008-00191.

109. Lohakare, J.D.; Ryu, M.H.; Hahn, T.-W.; Lee, J.K.; Chae, B.J. Effects of Supplemental Ascorbic Acid on the Performance and Immunity of Commercial Broilers. Journal of Applied Poultry Research 2005, 14, 10-19, doi:10.1093/japr/14.1.10.

110. Khodambashi Emami, N.; Zafari Naeini, S.; Ruiz-Feria, C.A. Growth Performance, Digestibility, Immune Response and Intestinal Morphology of Male Broilers Fed Phosphorus Deficient Diets Supplemented with Microbial Phytase and Organic Acids. Livestock Science 2013, 157, 506-513, doi:10.1016/j.livsci.2013.08.014.

111. Sugiharto, S. Role of Nutraceuticals in Gut Health and Growth Performance of Poultry. Journal of the Saudi Society of Agricultural Sciences 2016, 15, 99-111, doi:10.1016/j.jssas.2014.06.001.

112. Hu, Z.; Guo, Y. Effects of Dietary Sodium Butyrate Supplementation on the Intestinal Morphological Structure, Absorptive Function and Gut Flora in Chickens. Animal Feed Science and Technology 2007, 132, 240-249, doi:10.1016/j.anifeedsci.2006.03.017.

113. Smulikowska, S.; Czerwiński, J.; Mieczkowska, A.; Jankowiak, J. The Effect of Fat-Coated Organic Acid Salts and a Feed Enzyme on Growth Performance, Nutrient Utilization, Microflora Activity, and Morphology of the Small Intestine in Broiler Chickens. J. Anim. Feed Sci. 2009, 18, 478-489, doi:10.22358/jafs/66422/2009.

114. Stefanello, C.; Rosa, D.P.; Dalmoro, Y.K.; Segatto, A.L.; Vieira, M.S.; Moraes, M.L.; Santin, E. Protected Blend of Organic Acids and Essential Oils Improves Growth Performance, Nutrient Digestibility, and Intestinal Health of Broiler Chickens Undergoing an Intestinal Challenge. Front. Vet. Sci. 2020, 6, 491, doi:10.3389/fvets.2019.00491.

115. Centeno, C.; Arija, I.; Viveros, A.; Brenes, A. Effects of Citric Acid and Microbial Phytase on Amino Acid Digestibility in Broiler Chickens. British Poultry Science 2007, 48, 469-479, doi:10.1080/00071660701455276.

116. Cho, J. H.; Song, M. H.; Kim, I. H. Effect of microencapsulated blends of organic acids and essential oils supplementation on growth performance and nutrient digestibility in finishing pigs. Rev Colomb Cienc Pecu. 2014, 27, 264272.

117. Kluge, H.; Broz, J.; Eder, K. Effects of Dietary Benzoic Acid on Urinary PH and Nutrient Digestibility in Lactating Sows. Livestock Science 2010, 134, 119-121, doi:10.1016/j.livsci.2010.06.116.

118. Wang, J.P.; Yoo, J.S.; Lee, J.H.; Jang, H.D.; Kim, H.J.; Shin, S.O.; Seong, S.I.; Kim, I.H. Effects of Phenyllactic Acid on Growth Performance, Nutrient Digestibility, Microbial Shedding, and Blood Profile in Pigs. Journal of Animal Science 2009, 87, 3235-3243, doi:10.2527/jas.2008-1555.

119. Long, S.F.; Xu, Y.T.; Pan, L.; Wang, Q.Q.; Wang, C.L.; Wu, J.Y.; Wu, Y.Y.; Han, Y.M.; Yun, C.H.; Piao, X.S. Mixed Organic Acids as Antibiotic Substitutes Improve Performance, Serum Immunity, Intestinal Morphology and Microbiota for Weaned Piglets. Animal Feed Science and Technology 2018, 235, 23-32, doi:10.1016/j.anifeedsci.2017.08.018.

120. Gerritsen, R.; van Dijk, A.J.; Rethy, K.; Bikker, P. The Effect of Blends of Organic Acids on Apparent Faecal Digestibility in Piglets. Livestock Science 2010, 134, 246-248, doi:10.1016/j.livsci.2010.06.154. 
121. Mroz, Z.; Jongbloed, A.W.; Partanen, K.H.; Vreman, K.; Kemme, P.A.; Kogut, J. The Effects of Calcium Benzoate in Diets with or without Organic Acids on Dietary Buffering Capacity, Apparent Digestibility, Retention of Nutrients, and Manure Characteristics in Swine. Journal of Animal Science 2000, 78, 2622, doi:10.2527/2000.78102622x.

122. Liu, S.T.; Hou, W.X.; Cheng, S.Y.; Shi, B.M.; Shan, A.S. Effects of Dietary Citric Acid on Performance, Digestibility of Calcium and Phosphorus, Milk Composition and Immunoglobulin in Sows during Late Gestation and Lactation. Animal Feed Science and Technology 2014, 191, 67-75, doi:10.1016/j.anifeedsci.2014.01.017.

123. Devi, S.M.; Lee, K.Y.; Kim, I.H. Analysis of the Effect of Dietary Protected Organic Acid Blend on Lactating Sows and Their Piglets. R. Bras. Zootec. 2016, 45, 39-47, doi:10.1590/S1806-92902016000200001.

124. Khodambashi Emami, N.; Zafari Naeini, S.; Ruiz-Feria, C.A. Growth Performance, Digestibility, Immune Response and Intestinal Morphology of Male Broilers Fed Phosphorus Deficient Diets Supplemented with Microbial Phytase and Organic Acids. Livestock Science 2013, 157, 506-513, doi:10.1016/j.livsci.2013.08.014.

125. Ndelekwute, E.; Afolabi, K.; Uzegbu, H.; Essien, E. Effect of Dietary Formic Acid as Replacement of Streptomycin on Growth and Nutrient Digestibility in Broiler. Bang. J. Anim. Sci. 2015, 44, 69-74, doi:10.3329/bjas.v44i1.23146.

126. Ndelekwute, E.K.; Unah, U.L.; Udoh, U.H. Effect of dietary organic acids on nutrient digestibility, faecal moisture, digesta $\mathrm{pH}$ and viscosity of broiler chickens. MOJ Anat. Physiol. 2019,6, 40-43.

127. Ghazalah, A.A.; Atta, A.M.; Elkloub, K.; Moustafa, M.E.L.; Riry, F.H.S.; Effect of dietary supplementation of organic acids on performance, nutrients digestibility and health of broiler chicks. Int J Poult Sci, 2011, 10, 176-184

128. Cho, J. H.; Song, M. H.; Kim, I. H. Effect of microencapsulated blends of organic acids and essential oils supplementation on growth performance and nutrient digestibility in finishing pigs. Rev Colomb Cienc Pecu. 2014, 27, 264272 .

129. Jansons, I.; Jemeljanovs, A.; Konosonoka, I.H.; Sterna, V.; Lujane, B. The influence of organic acid additive, phytoadditive and complex of organic acid additive phytoadditive on pig productivity, meat quality. Agron. Res. 2011, 9, 389-394.

130. Brzóska, F.; Śliwiński, B.; Michalik-Rutkowska, O. Effect of Dietary Acidifier on Growth, Mortality, Post-Slaughter Parameters and Meat Composition of Broiler Chickens / Wpływ Zakwaszacza Diety Na Masę Ciała, Śmiertelność, Wydajność Rzeźną i Skład Mięsa Kurcząt Rzeźnych. Annals of Animal Science 2013, 13, 85-96, doi:10.2478/v10220-0120061-z.

131. Galli, G.M.; Aniecevski, E.; Petrolli, T.G.; Rosa, G. da; Boiago, M.M.; Simões, C.A.D.P.; Wagner, R.; Copetti, P.M.; Morsch, V.M.; Araujo, D.N.; et al. Growth Performance and Meat Quality of Broilers Fed with Microencapsulated Organic Acids. Animal Feed Science and Technology 2021, 271, 114706, doi:10.1016/j.anifeedsci.2020.114706.

132. Shin, Y.G.; Rathnayake, D.; Mun, H.S.; Dilawar, M.A.; Pov, S.; Yang, C.J. Sensory Attributes, Microbial Activity, Fatty Acid Composition and Meat Quality Traits of Hanwoo Cattle Fed a Diet Supplemented with Stevioside and Organic Selenium. Foods 2021, 10, 129, doi:10.3390/foods10010129.

133. Sugiharto, S.; Yudiarti, T.; Isroli, I.; Widiastuti, E.; Wahyuni, H.I.; Sartono, T.A.; Nurwantoro, N.; Al-Baarri, A.N. Effect of Dietary Supplementation of Formic Acid, Butyric Acid or Their Combination on Carcass and Meat Characteristics of Broiler Chickens. J. Indonesian Trop. Anim. Agric. 2019, 44, 286, doi:10.14710/jitaa.44.3.286-294.

134. El-Senousey, H.K.; Fouad, A.M.; Yao, J.H.; Zhang, Z.G.; Shen, Q.W. Dietary Alpha Lipoic Acid Improves Body Composition, Meat Quality and Decreases Collagen Content in Muscle of Broiler Chickens. Asian Australas. J. Anim. Sci 2013, 26, 394-400, doi:10.5713/ajas.2012.12430.

135. Menconi, A.; Kuttappan, V.A.; Hernandez-Velasco, X.; Urbano, T.; Matté, F.; Layton, S.; Kallapura, G.; Latorre, J.; Morales, B.E.; Prado, O.; et al. Evaluation of a Commercially Available Organic Acid Product on Body Weight Loss, 
Carcass Yield, and Meat Quality during Preslaughter Feed Withdrawal in Broiler Chickens: A Poultry Welfare and Economic Perspective. Poultry Science 2014, 93, 448-455, doi:10.3382/ps.2013-03444.

136. Attia, F.M. Effect of organic acids supplementation on nutrients digestibility, gut microbiota and immune response of broiler chicks. Egypt Poult Sci J. 2018, 38, 223-239.

137. Göksoy, E.Ö.; Aksit, M.; Kirkan, S. The effects of organic acid and origanum onites supplementations on some physical and microbial characteristics of broiler meat obtained from broilers kept under seasonal heat stress. Kafkas Univ. Vet. Fak. Derg, 2010, 16, S41-S46.

138. Jha, A.K.; Azad, Md.H.; Ali, Md.S.N.; Alam, P.; Sheikh, N.; Ali, H.; Ansari, K. Evaluation of Growth and Carcass Characteristics of Broiler Chickens (Cobb 500) Feed on Different Level of Organic Acids Inclusion in Diet at Parwanipur. Nep. Vet. J 2019, 36, 137-147, doi:10.3126/nvj.v36i0.27773.

139. Akbar, M.A.; Tewatia, B.S. Kumar, S. Effect of dietary supplementation of salts of organic acids on gut morphology and meat quality of broilers. Indian J Anim Res. 2018. 52(12).

140. Wen, C.; Chen, Y.; Leng, Z.; Ding, L.; Wang, T.; Zhou, Y. Dietary betaine improves meat quality and oxidative status of broilers under heat stress. J Sci Food Agric. 2019, 99(2), 620-623.

141. He, S.; Ding, J.; Xiong, Y.; Liu, D.; Dai Sand Hu, H. Effects of dietary fumaric acid on growth performance, meat quality, nutrient composition and oxidative status of breast muscle in broilers under chronic heat stress. Eur Poult Sci. 2020, 84, 1-11.

142. Ben Braïek, O.; Smaoui, S. Chemistry, Safety, and Challenges of the Use of Organic Acids and Their Derivative Salts in Meat Preservation. Journal of Food Quality 2021, 2021, 1-20, doi:10.1155/2021/6653190.

143. Scotter, M.J.; Castle, L. Chemical interactions between additives in foodstuffs: A review. Food Addit. Contam. 2004, 21, 93-124

144. Jamilah, M.B.; Abbas, K.A.; Rahman, R.A. A review on some organic acids additives as shelf life extenders of fresh beef cuts. Am. J. Agric. Biol. Sci. 2008, 3, 566.

145. Hauser, C.; ielmann, J.; Muranyi, P. Organic acids: usage and potential in antimicrobial packaging," in Antimicrobial Food Packaging, Academic Press, Cambridge, MA, USA, 2016, pp. 563-580

146. Nair, M.S.; Nair, D.V.T.; Johny, A.K.; Venkitanarayanan, K. Use of food preservatives and additives in meat and their detection techniques. In Meat Quality Analysis; Biswas, A.K., Mandal, P.K., Eds.; Academic Press: London, UK, 2020; pp. 187-213. ISBN 978-0-12-819233-7

147. O'Connor, P.L.; Brewer, M.S.; Mckeith, F.K.; Novakofski, J.E.; Carr, T.R. Sodium Lactate/Sodium Chloride Effects on Sensory Characteristics and Shelf-Life of Fresh Ground Pork. J Food Science 1993, 58, 978-980, doi:10.1111/j.13652621.1993.tb06092.x.

148. Kim, T.K.; Hwang, K.E.; Lee, M.A.; Paik, H.D.; Kim, Y.B.; Choi, Y.S. Quality characteristics of pork loin cured with green nitrite source and some organic acids. Meat science, 2019, 152, 141-145

149. Carpenter, C.E.; Smith, J.V.; Broadbent, J.R. Efficacy of Washing Meat Surfaces with 2\% Levulinic, Acetic, or Lactic Acid for Pathogen Decontamination and Residual Growth Inhibition. Meat Science 2011, 88, 256-260, doi:10.1016/j.meatsci.2010.12.032.

150. Dan, S. D.; Mihaiu, M.; Reget, O.; Oltean, D.; Tabaran, A. Influence on week organic acids on pathogens on swine carcasses. Lucrari Stiintifice-Medicina Veterinara, Universitatea de Stiinte Agricole si Medicina Veterinara, Ion Ionescu de la Brad, Iasi, vol. 60, pp. 265-273, 2017. 
151. González Sánchez, S. V. Efficacy of antimicrobial treatments against Salmonella enterica on pork and Campylobacter jejuni on poultry, Doctoral Dissertation, Colorado State University, Fort Collins, CO, USA, 2020.

152.Gonzalez-Fandos, E.; Martinez-Laorden, A.; Perez-Arnedo, I. Effect of Decontamination Treatments on Campylobacter Jejuni in Chicken. Foods 2020, 9, 1453, doi:10.3390/foods9101453.

153. Stamilla, A.; Russo, N.; Messina, A.; Spadaro, C.; Natalello, A.; Caggia, C.; Randazzo, C.L.; Lanza, M. Effects of Microencapsulated Blend of Organic Acids and Essential Oils as a Feed Additive on Quality of Chicken Breast Meat. Animals 2020, 10, 640, doi:10.3390/ani10040640.

154. Suman, S.P.; Joseph, P. Myoglobin Chemistry and Meat Color. Annu. Rev. Food Sci. Technol. 2013, 4, 79-99, doi:10.1146/annurev-food-030212-182623.

155. Yang, X.; Wang, J.; Feng, Z.; Zhang, X.; Wang, X.; Wu, Q. Relation of the PdxB-Usg-TruA-DedA Operon and the TruA Gene to the Intracellular Survival of Salmonella Enterica Serovar Typhimurium. IJMS 2019, 20, 380, doi:10.3390/ijms20020380.

156. Bearson, S.; Bearson, B.; Foster, J.W. Acid stress responses in enterobacteria. FEMS Microbiol. Lett. 1997, 147, $173-$ 180.

157. Barua, S.; Yamashino, T.; Hasegawa, T.; Yokoyama, K.; Torii, K.; Ohta, M. Involvement of surface polysaccharides in the organic acid resistance of Shiga Toxin-producing Escherichia coli O157:H7. Mol.Microbiol. 2002, 43, 629-640

158. Foster, J.W. The acid tolerance response of Salmonella typhimurium involves transient synthesis of key acid shock proteins. J. Bacteriol. 1993, 175, 1981-1987

159. Foster, J.W. Salmonella acid shock proteins are required for the adaptive acid tolerance response. J. Bacteriol.1991, $173,6896-6902$.

160. Hume ME, Corrier DE, Ivie GW, DeLoach JR. Metabolism of [14C] propionic acid in broiler chickens. Poult Sci. (1993) 72:786-93. doi: 10.3382/ps.0720786

161. Conner, D.E.; Kotrola, J.S. Growth and Survival of Escherichia Coli O157:H7 under Acidic Conditions. Applied and environmental microbiology 1995, 61, 382-385, doi:10.1128/AEM.61.1.382-385.1995.

162. Kwon, Y.M.; Park, S.Y.; Birkhold, S.G.; Ricke, S.C. Induction of Resistance of Salmonella Typhimurium to Environmental Stresses by Exposure to Short-Chain Fatty Acids. J Food Science 2000, 65, 1037-1040, doi:10.1111/j.13652621.2000.tb09413.x.

163. Kwon, Y.M.; Park, S.Y.; Birkhold, S.G.; Ricke, S.C. Induction of Resistance of Salmonella Typhimurium to Environmental Stresses by Exposure to Short-Chain Fatty Acids. J Food Science 2000, 65, 1037-1040, doi:10.1111/j.13652621.2000.tb09413.x.

164. Thompson, J.L.; Hinton, M. Antibacterial Activity of Formic and Propionic Acids in the Diet of Hens on Salmonellas in the Crop. British Poultry Science 1997, 38, 59-65, doi:10.1080/00071669708417941.

165. Dickens, J.A.; Lyon, B.G.; Whittemore, A.D.; Lyon, C.E. The Effect of an Acetic Acid Dip on Carcass Appearance, Microbiological Quality, and Cooked Breast Meat Texture and Flavor. Poultry Science 1994, 73, 576-581, doi:10.3382/ps.0730576.

166. Dickens, J.A.; Whittemore, A.D. The Effect of Acetic Acid and Air Injection on Appearance, Moisture Pick-Up, Microbiological Quality, and Salmonella Incidence on Processed Poultry Carcasses. Poultry Science 1994, 73, 582-586, doi:10.3382/ps.0730582. 
167. Gabert, V.M.; Sauer, W.C. The Effect of Fumaric Acid and Sodium Fumarate Supplementation to Diets for Weanling Pigs on Amino Acid Digestibility and Volatile Fatty Acid Concentrations in Ileal Digesta. Animal Feed Science and Technology 1995, 53, 243-254, doi:10.1016/0377-8401(94)00750-4.

660 661 662 